\title{
South Anyui suture: tectono-stratigraphy, deformations, and principal tectonic events
}

\author{
S. D. Sokolov ${ }^{1}$, G. Ye. Bondarenko ${ }^{2}$, P. W. Layer ${ }^{3}$, and I. R. Kravchenko-Berezhnoy ${ }^{1}$ \\ ${ }^{1}$ Geological Institute, Russian Academy of Sciences, Moscow, Russia \\ ${ }^{2} \mathrm{ZAO}$ "Rusnetegaz", Moscow, Russia \\ ${ }^{3}$ Geophysical Institute, Alaskan University, Fairbanks, USA
}

\begin{abstract}
Geochronologic and structural data from the terranes of the South Anyui suture zone record a protracted deformational history before, during and after an Early Cretaceous collision of the passive margin of the Chukotka-Arctic Alaska continental block with the active continental margin of the North Asian continent. Preceding this collision, the island arc complexes of the Yarakvaam terrane on the northern margin of the North Asian craton record Early Carboniferous to Neocomian ages in ophiolite, sedimentary, and volcanic rocks. Triassic to Jurassic amphibolites constrain the timing of subduction and intraoceanic deformation along this margin. The protracted (Neocomian to Aptian) collision of the Chukotka passive margin with the North Asian continent is preserved in a range of structural styles including first north verging folding, then south verging folding, and finally late collisional dextral strike slip motions which likely record a change from orthogonal collision to oblique collision. Due to this collision, the southern passive margin of Chukotka was overthrust by tectonic nappes composed of tectono-stratigraphic complexes of the South Anyui terrane. Greenschists with ages of 115-119 Ma are related to the last stages of this collision. The postcollisional orogenic stage (Albian to Cenomanian) is characterized by sinistral strike slip faults and an extensional environment.
\end{abstract}

\section{Introduction}

The South Anyui suture (SAS) is an important tectonic feature of the Mesozoic fold-and-thrust belts of NE Asia (referred to as the Mesozoides in Russian literature) (Fig. 1). Structures located to the north and south of the SAS have dissimilar geology and deformation histories. North of the SAS, structures of the Anyui-Chukotka fold-and-thrust belt are

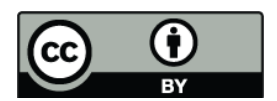

Correspondence to: S. D. Sokolov (sokolov@ginras.ru) composed mainly of Paleozoic-Mesozoic continental margin sedimentary cover. Precambrian metamorphic basement schists are encountered locally in eastern Chukotka. South of the SAS, structures of the Alazeya-Oloy fold-and-thrust belt are composed of island arc terranes of Paleozoic and Mesozoic age that are considered part of the Kolyma Loop (Zonenshain et al., 1990; Fig. 1).

The SAS has been customarily viewed as a collisional suture formed by closure of a Late Jurassic-Early Cretaceous oceanic basin and collision of the North Asian craton with the Arctic-Alaska Chukotka terrane of the North American continent (Parfenov and Natal'in, 1977; Seslavinsky, 1979; Parfenov, 1984). Many aspects of the geological setup of the SAS remain poorly understood and there are dissenting viewpoints on the following issues: (i) location of the boundaries of the SAS and their likely westward and eastward extensions (Fig. 1, inset); (ii) the origin and age of the oceanic basin; (iii) tectonic history; (iv) timing of the onset and termination of collision.

We have obtained geological, structural and ${ }^{40} \mathrm{Ar} /{ }^{39} \mathrm{Ar}$ geochronological data (presented in Table 1 in the Supplement: http://www.stephan-mueller-spec-publ-ser.net/4/201/ 2009/smsps-4-201-2009-supplement.pdf), affording essential constraints on the particulars of SAS geology and the principal stages of its tectonic history.

\section{Geological framework}

SAS structures are exposed in the catchment areas of the Bolshoy Anyui and Malyi Anyui rivers, where they have been identified as a separate tectonic unit known as the South Anyui zone (e.g., Til'man et al., 1975, 1977; Seslavinsky, 1979), or the South Anyui terrane (Parfenov et al., 1993; Nokleberg et al., 1994). Based on geological and geophysical data, the SAS extends northwestward beneath the deposits of the Primorskaya depression (Spector et al., 1981; Parfenov, 1984). In the northwest, the last outcrops of the

Published by Copernicus Publications on behalf of the European Geosciences Union. 
Tectonic scheme of Northeastern Russia

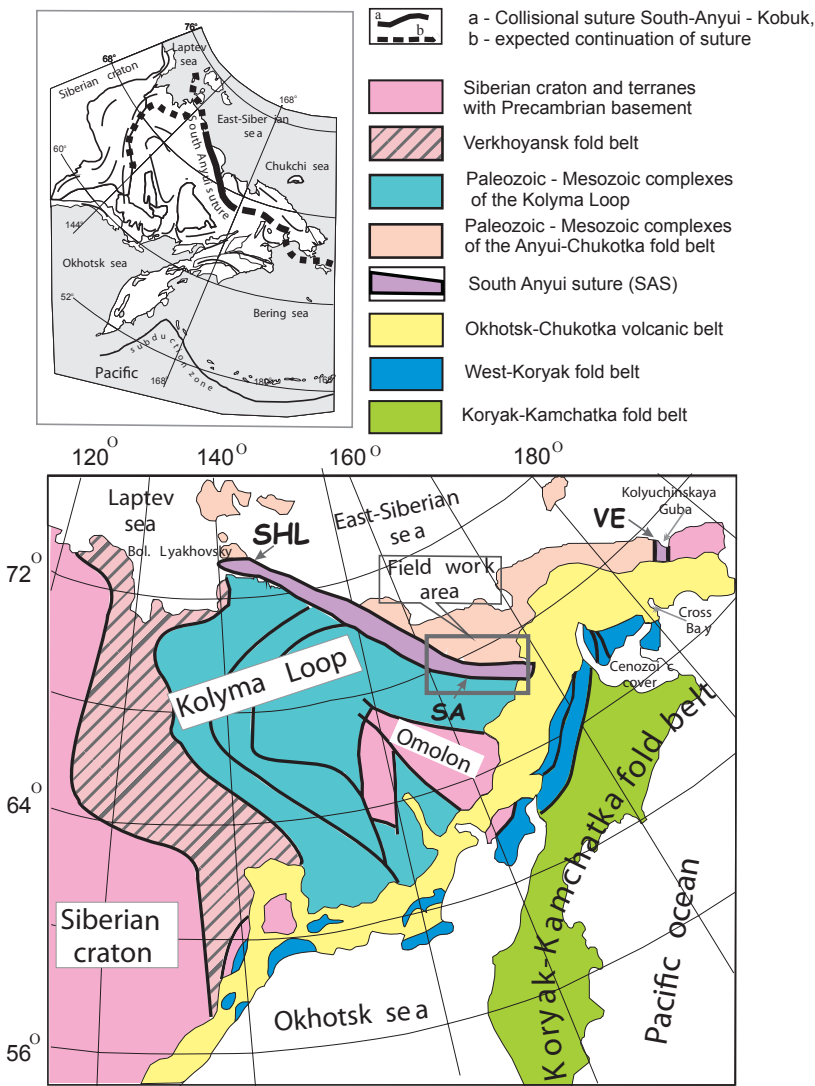

SHL - Shalaurova terrane; SA-South-Anyui terrane; VE-Velmai terrane

Fig. 1. Tectonic scheme of Northeastern Russia.

SAS complexes are known to occur in Bolshoi Lyakhovski Island (Fig. 1). They consist of ophiolite fragments, amphibolites, and glaucophane shists of Paleozoic (Drachev and Savostin, 1993) or Mesozoic age (Kuz'michev et al., 2005). However, further westward extension of the suture remains unclear. The inset in Fig. 1 shows the likely extensions of the SAS. Many workers have been trying to find the SAS extension onto the shelf. However, the continuation of SAS structures is not expressed distinctly in gravity and magnetic anomalies. It cannot be precluded, that its immediate extension may be provided by the ophiolitic allochthons of the Kolyma Loop. The geodynamic settings of the Cherski and SAS ophiolites are similar (Oxman et al., 2004).

To the east, in the upper reaches of the Bolshoy Anyui and Malyi Anyui rivers, the SAS structures are covered by the Okhotsk-Chukotka volcanic belt (Fig. 1). It has been proposed that eastern extension of the SAS include complexes of the Velmai terrane in Eastern Chukotka and the Angayucham terrane in Alaska (Parfenov, 1984; Parfenov et al., 1993; Bondarenko, 2004). Note that Leonid Parfenov was the first to propose the structural connection between SAS and Kobuk suture in Alaska. No consensus exists as to the north and south SAS boundaries, either. Lychagin et al. (1991) view the Aluchin and Vurguveyem ophiolites to be the essential part of the SAS, while Natal'in (1984) incorporates Upper Jurassic-Lower Cretaceous island arc complexes. Other workers (Til'man et al., 1977; Parfenov, 1984; Zonenshain et al., 1990 and others) attribute these complexes to the Alazeya-Oloy fold belt and not to the SAS.

The SAS has been customarily viewed as a structure resulting from closure of an oceanic basin. However, there are different viewpoints as to the origin and age of this basin. Some workers interpret the South Anyui basin as a continental rift (Til'man et al., 1977; Shapiro and Ganelin, 1988; Chekhov, 2000), while others, as a re-entrant of the PaleoPacific (Churkin, 1983; Fujita and Newberry, 1982; Parfenov, 1984; Savostin et al., 1984; Zonenshain et al., 1990; Nokleberg et al., 1998) or as a remnant of the Paleo-Arctic Ocean separated by a convergent margin from the PaleoPacific (Parfenov, 1997; Sokolov et al. 1997).

The age of the South Anyui oceanic basin was generally considered to be Late Jurassic-Early Cretaceous (e.g., Til'man et al., 1977; Natal'in, 1984; Parfenov, 1984; Shapiro and Ganelin, 1988; Chekhov, 2000; Nokleberg et al., 1994, 1998). These concepts were based on faunal determinations from clastic rocks that included horizons of basalts and cherts. The advocates of rifting assign the onset of formation to the Early Triassic (Natal'in et al. 1999; Savostin et al., 1984) or to the Late Jurassic (Shapiro and Ganelin, 1988; Nokleberg et al., 1998; Chekhov, 2000). Supporters of the existence of an oceanic basin in the Paleozoic (the "relict" viewpoint) draw mainly on paleomagnetic and paleobiogeographic data (Fujita and Newberry, 1982; Ustritsky and Khramov, 1987; Zonenshain et al., 1990; Golonka et al., 1994), as well as rare geological observations (Lychagin et al., 1991; Cecile et al., 1991; Drachev and Savostin, 1993). However, the recent studies on Bolshoi Lyakhovsky Island (Kuz'michev et al., 2005a) cast doubt on the Paleozoic age of the ophiolites of the Shalaurova terrane (Drachev and Savostin, 1993). For this reason, the issue of the existence of the South Anyui oceanic basin in the Late Paleozoic and Early Mesozoice remains open to discussion.

Within the South Anyui suture zone, three terranes are recognized: the Shalaurova ophiolitic terrane, the Velmai terrane, and the South Anyui terrane (Fig. 1). This paper presents new geochronological $\left({ }^{40} \mathrm{Ar} /{ }^{39} \mathrm{Ar}\right)$ ages as well as geologic and structural data from these terranes as well as from the adjacent Yarakvaam terrane, Our new data better constrains the tectonic histories of the South Anyui Suture zone.

\section{Geochronologic analyses}

For ${ }^{40} \mathrm{Ar} /{ }^{39} \mathrm{Ar}$ analysis, samples were submitted to the Geochronology Laboratory at the University of Alaska, Fairbanks. In general, 100-250 micron-sized minerals or 
whole-rock chips were separated. The monitor mineral MMhb-1 (Samson and Alexander, 1987) with an age of 513.9 Ma (Lanphere and Dalrymple, 2000) was used to monitor neutron flux (and calculate the irradiation parameter, $J$ ). The samples and standards were wrapped in aluminum foil and loaded into aluminum cans of $2.5 \mathrm{~cm}$ diameter and $6 \mathrm{~cm}$ height. The samples were irradiated in position $5 \mathrm{c}$ of the uranium enriched research reactor of McMaster University in Hamilton, Ontario, Canada for $20 \mathrm{MWh}$.

Upon their return from the reactor, the samples and monitors were loaded into $2 \mathrm{~mm}$ diameter holes in a copper tray that was then loaded in a ultra-high vacuum extraction line. The monitors were fused, and samples heated, using a 6-watt argon-ion laser following the technique described in York et al. (1981), Layer et al. (1987) and Layer (2000). Argon purification was achieved using a liquid nitrogen cold trap and a SAES $\mathrm{Zr}$-Al getter at $400^{\circ} \mathrm{C}$. The samples were analyzed in a VG-3600 mass spectrometer at the Geophysical Institute, University of Alaska Fairbanks. The argon isotopes measured were corrected for system blank and mass discrimination, as well as calcium, potassium and chlorine interference reactions following procedures outlined in McDougall and Harrison (1999). System blanks generally were $2 \times 10^{-16} \mathrm{~mol}^{40} \mathrm{Ar}$ and $2 \times 10^{-18} \mathrm{~mol}^{36} \mathrm{Ar}$, which are 10 to 50 times smaller than fraction volumes. Mass discrimination was monitored by running both calibrated air shots and a zero-age glass sample. These measurements were made on a weekly to monthly basis to check for changes in mass discrimination.

A summary of all the ${ }^{40} \mathrm{Ar} /{ }^{39} \mathrm{Ar}$ results is given in Table 1 and the spectra are shown in Fig. 2, with all ages quoted to the $\pm 1 \sigma$ level and calculated using the constants of Steiger and Jaeger (1977). The integrated age is the age given by the total gas measured and is equivalent to a potassium-argon (K-Ar) age. The spectrum provides a plateau age if three or more consecutive gas fractions represent at least $50 \%$ of the total gas release and are within two standard deviations of each other (Mean Square Weighted Deviation less than $\sim 2.5$ ). Isochron ages could be calculated for all but one sample (98117/3, which had insufficient isotopic variation to allow for isochron calculation). With the exception of one sample (C-2572/9), isochron ages agree with plateau ages at the 2- $\sigma$ level, so, for the basis of discussion, we prefer to use plateau ages for the samples.

\section{Terranes of the South Anyui suture zone}

\subsection{Shalaurova ophiolitic terrane}

The western most portion of the South Anyui suture is the Shalaurova ophiolitic terrane first identified by Parfenov et al. (1993) in the southeastern part of the Bolshoy Lyakhovsky Island, on Cape Shalaurov (Fig. 1). It comprises serpentinized peridotites, gabbro-diabase, MORB-like pillow basalts with a Sm-Nd age of $291 \pm 62 \mathrm{Ma}$, amphibolites with a K-Ar age of $473 \mathrm{Ma}$ (Drachev and Savostin, 1993), and glaucophane schists (Kuz'michev et al., 2005b).

The metamorphic rocks and ophiolites are spatially associated with graywacke flysch of the Burustass Formation and occur as tectonic wedges and thrust sheets. Formerly, this formation was dated as Permian; however, recent fission track data on detrital zircons (ca. $160 \mathrm{Ma}$ ) point to it being younger, probably Late Jurassic to Neocomian in age (Kuz'michev et al., 2005b). The flysch probably accumulated in a foredeep built during the collision of the AnyuiSvyatoy Nos arc to the south and the New Siberian continental block to the north (Kuz'michev et al., 2005a).

Two types of amphibolites are distinguished (Kuz'michev et al., 2005b). One of them, along with glaucophane schist, metabasalt, and metagabbro, makes up a coherent glaucophane amphibolite complex, composed of volcanic and sedimentary rocks associated with the subducting oceanic crust of the South Anyui basin. The $P-T$ parameters of metamorphism point to "warm" subduction setting. Another type of amphibolite is of suprasubduction genesis and is interpreted as a crustal fragment of the lower part of an island arc.

The ages of the metamorphic rocks and the ophiolite assemblage are not constrained, because reliable geochronologic data are lacking. The Sm-Nd age of the pillow basalts $(291 \pm 62 \mathrm{Ma}$ ) is a bulk rock age (Drachev and Savostin, 1993). While $133.5 \pm 4.5 \mathrm{Ma}$ and $139 \pm 8 \mathrm{Ma} \mathrm{K}-\mathrm{Ar}$ ages of interpillow hyaloclastite are more likely to record younger events (Kuz'michev et al., 2005b). In our opinion, the Valanginian age corresponds to the final phase of subduction, formation of accretionary prisms, and the beginning of tectonic juxtaposition of the Chukotka microcontinent with the structures of the active margin of the North Asian continent. Late-stage granites dated at $114.4 \pm 0.5 \mathrm{Ma}$ (biotite ${ }^{40} \mathrm{Ar} /{ }^{39} \mathrm{Ar}$ plateau age) provide a lower bound to the age of deformation (Layer et al., 2001). We are inclined to interpret the Shalaurov terrane as an accretionary prism with tectonically incorporated fragments of oceanic lithosphere (basalt, peridotite) and exhumed metamorphites of subduction genesis and lower crust fragments of an island arc.

\subsection{Velmai terrane}

First identified by S. D. Sokolov (Parfenov et al., 1993; Nokleberg et al., 1994), the Velmai terrane is comprised of ultramafics, gabbro, plagiogranite, and terrigenous, siliceous, and volcanic deposits widespread south of the Kolyuchinskaya Guba and north of Cross Bay in Chukotka Peninsula (Fig. 1). It consists predominantly of tectonic melange (Kosygin et al., 1974), typical of disintegrated rocks of the ophiolite assemblage. Different viewpoints exist regarding the age of the rocks. Some workers based on Buchia finds in clastic rocks date the entire complex to the Upper Jurassic-Lower Cretaceous (Kosygin et al., 1974), while others to the Upper Triassic (Norian) based on Monotis and radiolarian finds in 

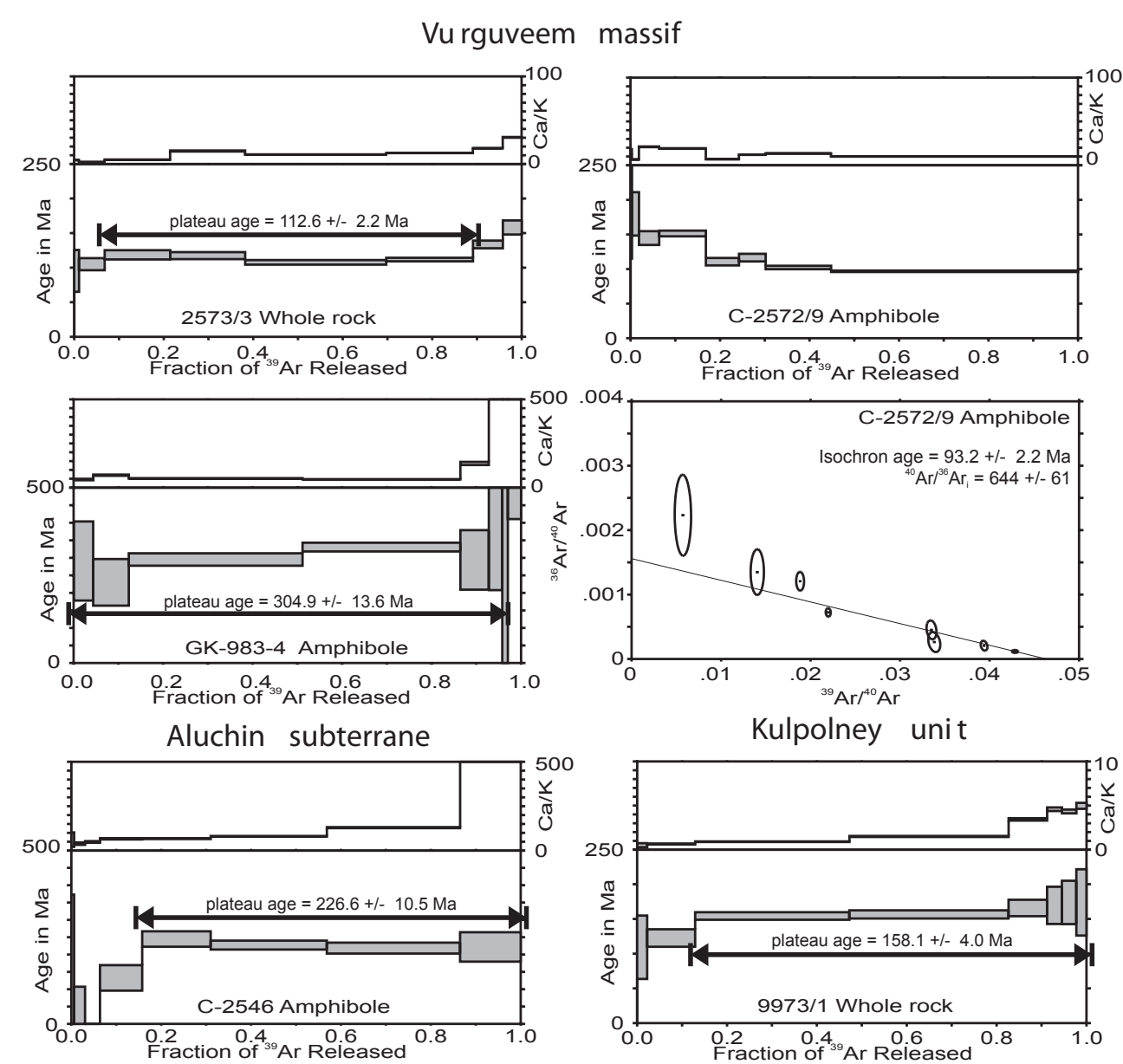

Kulpolney unit

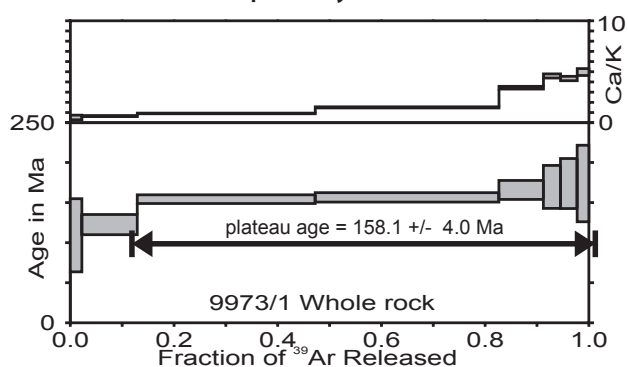

Penvel'veem unit

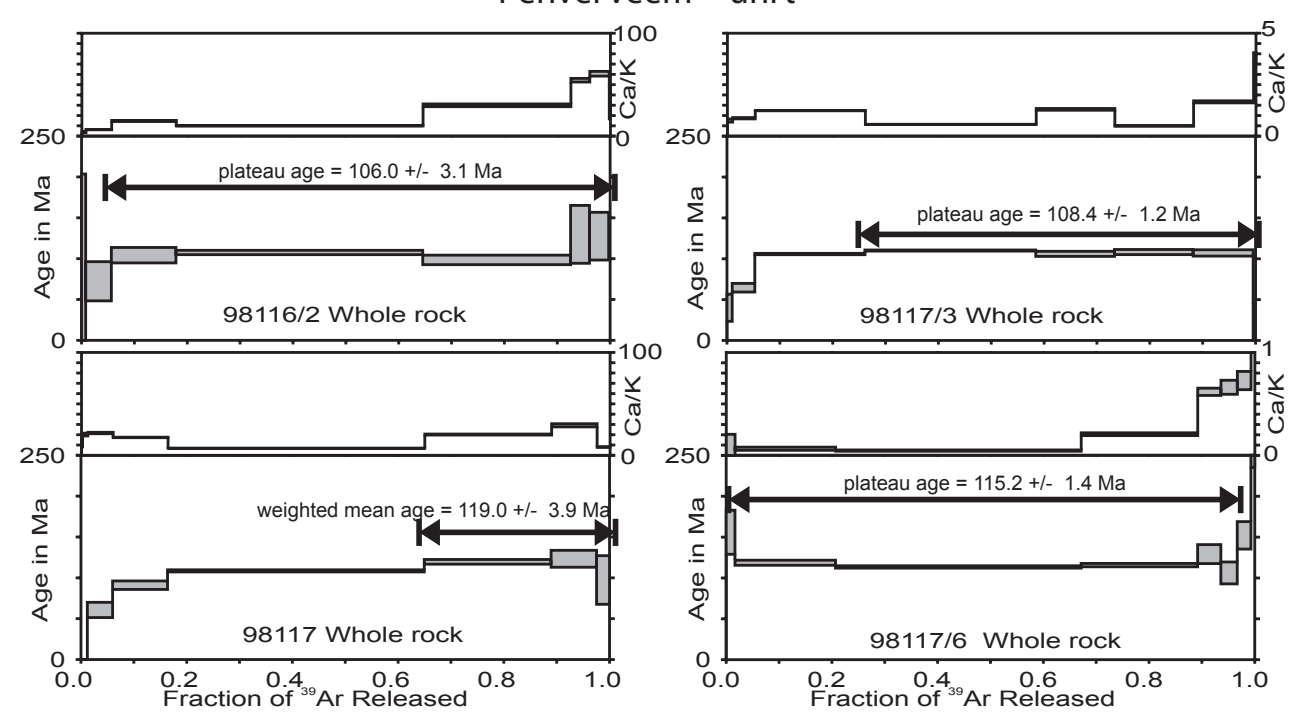

Fig. 2. ${ }^{40} \mathrm{Ar} /{ }^{39} \mathrm{Ar}$ age and $\mathrm{Ca} / \mathrm{K}$ spectra from whole rock and mineral separates from the South Anyui suture zone. Heights of boxes are $\pm 1 \sigma$, and ages are quoted to $\pm 1 \sigma$. Sample C-2572/9 is the only one with significant excess argon. No plateau could be calculated for this sample. An inverse isochron plot is shown, with a best-fit isochron for all fractions. Sample 98117 has an age spectrum indicative of severe argon loss. Age is a weighted age of the three oldest fractions, but because of argon loss, probably represents a minimum age. Whole rock sample M02$56 / 1$ does not exhibit either an isochron or plateau. See Table 1 for details of plateau and isochron calculations, and Supplement for analytical data and an explanation of methods (see http://www.stephan-mueller-spec-publ-ser.net/4/201/2009/smsps-4-201-2009-supplement.pdf). 


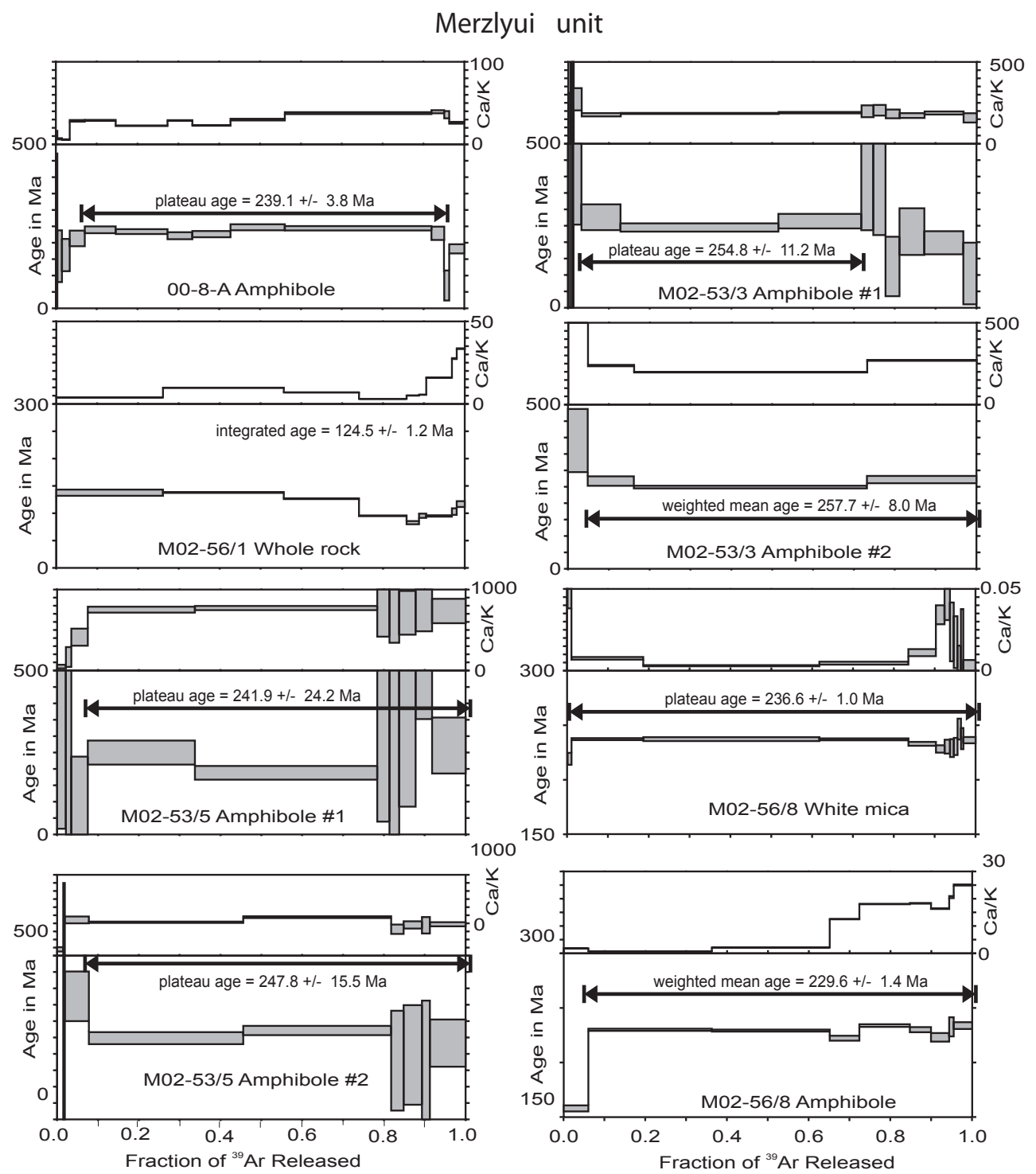

Fig. 2. Continued.

siliceous and tuffaceous terrigenous rocks (Tynankergav and Bychkov, 1987). These workers point out that the Norian faunas differ from the faunas known from the neighboring regions of Chukotka and resemble faunas from Alaska and tuffaceous terrigenous sequences of the Norian Stage on the Bolshoy Anyui River within the Yarakvaam terrane.

It is quite likely that here, just as in the Shalaurova terrane, fragments of an accretionary prism with disintegrated inclusions of ophiolites and oceanic crust exist. The lack of reliable data on the composition of the volcanics prevents determination of the geodynamic setting of their formation. However, the presence of pyroclastic rocks and tuffaceous silicites suggests that island arc complexes are present as well as ophiolites.

\subsection{South Anyui terrane}

The South Anyui terrane (Parfenov et al., 1993; Nokleberg et al., 1994, 1998) is identified as an accretionary wedge terrane. Aptian and Albian volcanic and sedimentary rocks (Shekhovtsov and Glotov, 2001) of the Kameshkov, Ainakhkurgen and Nutesyn depressions are the overlap sequences (Fig. 3). After the work of Natal'in (1984), it has been common belief (Zonenshain et al., 1990; Ti'lman and Bogdanov, 1992) that island arcs rimmed the South Anyui oceanic basin to the north (Nutesyn island arc) and south (Oloi island arc).

The first descriptions of the accretionary prism (the South Gremuchinsky complex) was provided by Sokolov et al. (2001, 2002), Bondarenko (2004). These studies have 

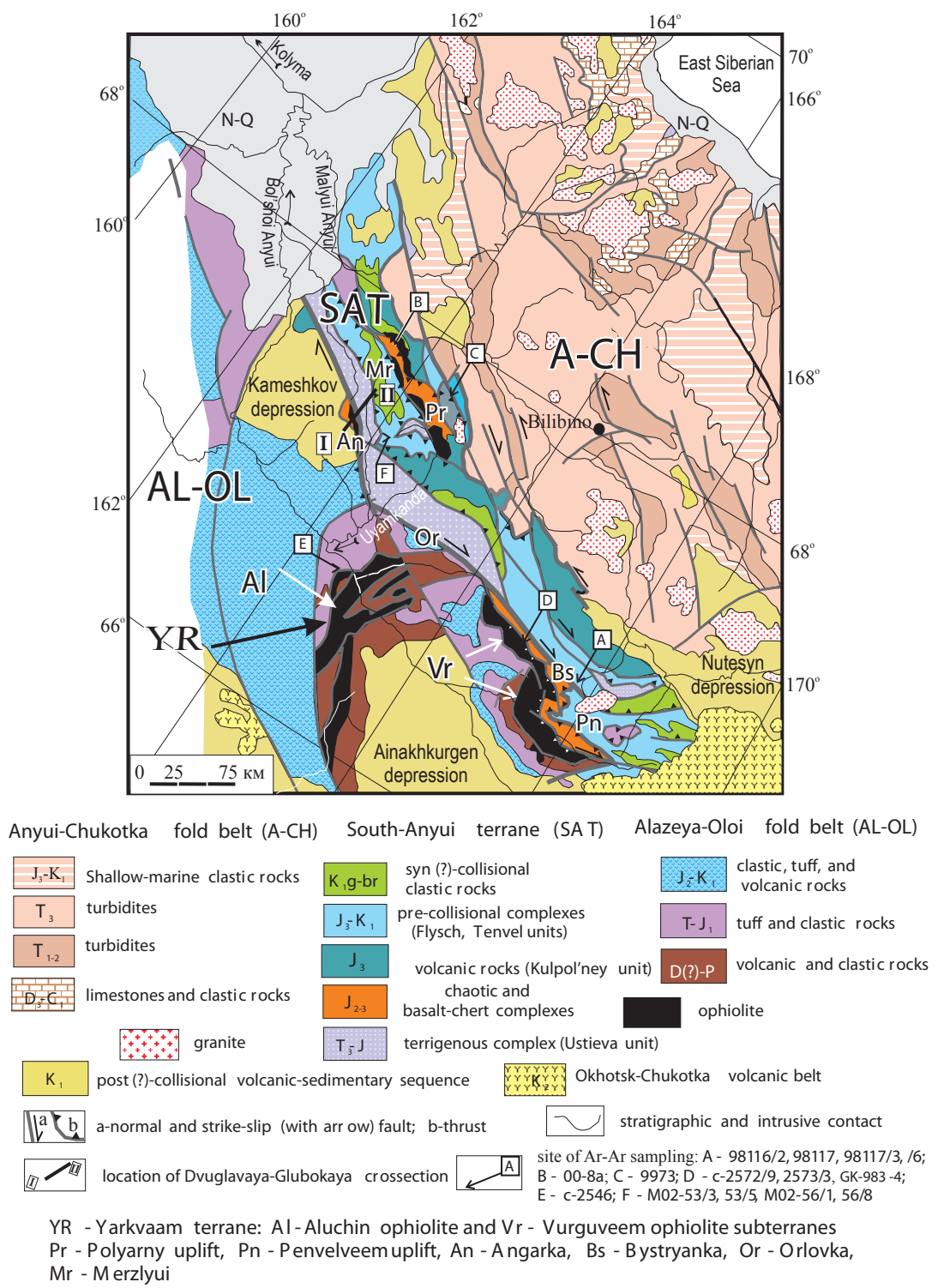

Fig. 3. Tectono-stratigraphic map of Western Chukotka. Compiled by S. D. Sokolov and G. Ye. Bondarenko using their own data and state geological survey maps of 1:200 000 scale (Q-58-III, IV; Q-58-V,VI; Q-58-IX, X; Q-58-XI, XII; Q-58-XV, XVI; Q-58-XVII, XVIII).

demonstrated that the SAS consists of a system of intricately deformed thrust sheets that were thrust northward onto the Triassic deposits of the Chukotka microcontinent forming the Anyui-Chukotka fold and thrust belt.

The thrust sheets consist of the following tectonostratigraphic complexes (units): (i) autochthonous terrigenous rocks (Ustieva unit); (ii) carbonate, siliceous, and volcanic rocks (Polyarny unit); (iii) sedimentary and volcanic rocks (Kulpol'ney unit), (iv) turbidites (Flysch unit); (v) terrigenous and volcanic rocks (Tenvel unit); (vi) chaotic complex (South Gremuchinsky 'unit); (vii) siliceous rocks and basalt (Bystryanka unit); (viii) a dismembered ophiolite complex (Merzlyui unit); and (ix) terrigenous, tuffaceous, and volcanic rocks (Pen'velveem unit). These units presumably formed in different parts of the oceanic basin and at its margins (Fig. 4). Description of these units is given below.

\subsection{Tectono-stratigraphic units of the South Anyui terrane}

\subsubsection{Ustieva unit}

This unit consists of autochthonous distal turbidites of the Chukotka microcontinent. It occupies the lowermost structural position and is composed of an alternation, often rhythmic, of sandstone, siltstone, and mudstone with sulfidecabonate concretions. Sandstone grains consist of quartz (70-90\%), feldspar, and less abundant sedimentary clasts and 


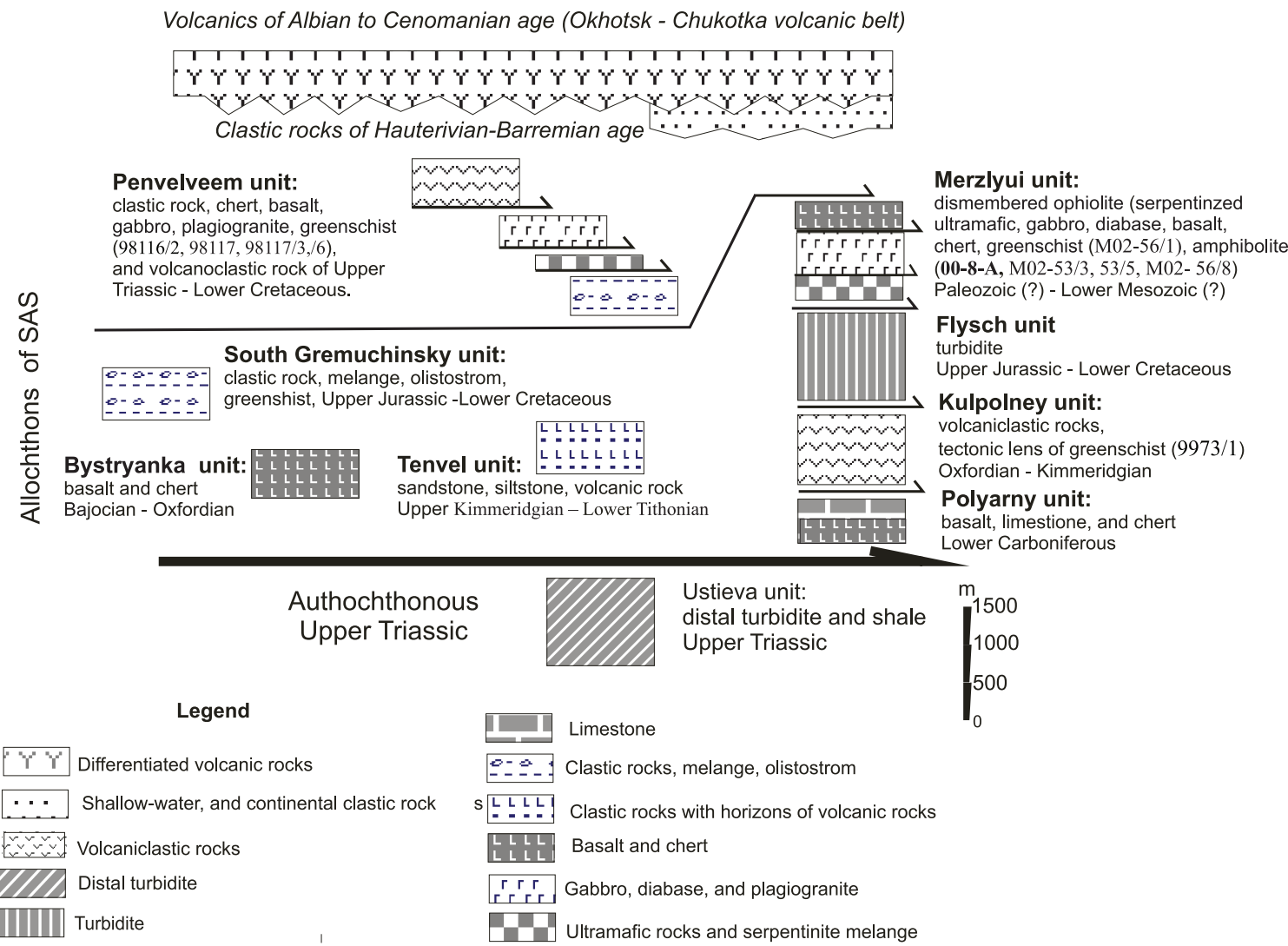

Fig. 4. Tectono-stratigraphic units of the South-Anyui terrane.

pyroxene. Measurements of the persistent system of bottom current marks suggest a north to south clastic supply (present reference frame). Based on single (sporadic) finds of Monotis and Otapiria shells and conodonts, this sequence is attributed to the Norian Stage of the Upper Triassic (Glotov, 1995; Shekhovtsov and Glotov, 2001; Sokolov et al., 2002).

\subsubsection{Polyarny unit}

This unit is composed of carbonate, siliceous, and volcanic rocks exposed on the Polyarny uplift (Fig. 3), where tectonic and erosion windows display volcanics and limestones with corals of Carboniferous age (Sizykh et al., 1977). The volcanics are pillow and massive basalts with lenses of red cherts. The basalts have geochemical fingerprints resembling MORBs, and the presence of a Nb-minimum in the Rare Earth Element (REE) suggests their origin in a marginal sea (Sokolov et al., 2006). The upper part of the stratigraphy contains sporadic intercalations up to $1-2 \mathrm{~m}$ thick of gray, black, and greenish cherts. The cherts contain small radiolarian remains, recrystallized beyond recognition. Limestones occur stratigraphically higher or are encountered in the form of blocks among the volcanics (Sokolov et al., 2006).

Advocates of rift-related origin for the SAS interpreted the Carboniferous deposits as preserved relics of pre-Mesozoic basement (Sizykh et al., 1977; Shapiro and Ganelin, 1988; Lychagin, 1997). The studies of Bondarenko (2004) show that the complex of carbonate, siliceous, and volcanic rocks makes up an allochthonous unit in a complex package of tectonic slices thrust onto terrigenous Triassic deposits of the Chukotka microcontinent. This complex is a fragment of oceanic crust testifying to the existence of the South Anyui oceanic basin as early as the Late Paleozoic (Sokolov et al., 2006).

\subsubsection{Kulpolney unit}

This sedimentary and volcanic complex is widespread in the northern part of the SAS (Fig. 3). Its lower contact is tectonic. In places along the contact, green schists, bodies of gabbro and ultramafic rocks are encountered; these are viewed as the basement of the complex (Shekhovtsov and Glotov, 2001). On the Polyarny uplift, this complex is located structurally above the complex of carbonate, siliceous, and volcanic rocks of Carboniferous age. A whole rock analysis from green schist has a plateau age of $158.1 \pm 4.0 \mathrm{Ma}$ (sample 9973/1, Table 1; Fig. 2). Probably this age corresponds to time of deformations or subduction in intraoceanic arc. 
This unit contains of various types of volcanic rocks that include pillow lavas and massive amygdular basalts, andesites, dacites, and their subvolcanic and pyroclastic counterparts. The volcanic rocks alternate with, or are replaced along strike by, tuffaceous and volcanoclastic rocks and graywackes. The proportion of the volcanic relative to sedimentary rocks changes from section to section. In the catchment area of the Kul'polney and Nutesyn rivers, volcanics and their pyroclastic counterparts are predominant, and on the Polyarny uplift, tuffaceous and sedimentary rocks are. The volcanic rocks display calcalkaline and subalkaline trends and may have formed in an island-arc setting (Natal'in, 1984; Lychagin et al., 1991; Sokolov et al., 2002; Bondarenko, 2004). In the Polyarny uplift and in the catchment area of the Kul'polney River this complex includes Oxfordian-Kimmeridgian marine faunas (Shekhovtsov and Glotov, 2001).

\subsubsection{Flysch unit}

The Flysch unit is a turbidite complex composed of rhythmically alternating sandstone, siltstone, and mudstone. The turbidite horizons (members, layers) alternate with or give way laterally to horizons of thinly alternating siltstone and mudstone with sporadic intercalations of sandstone. Distal and proximal turbidites are discriminated. The sandstones are of polymict composition. The turbidites yield Tithonian to Valanginian faunas (Shekhovtsov and Glotov, 2001). At that time spreading ceased and South Anyui ocean was a relic basin, which began to close and fill by turbidites (Sokolov et al., 2002; Bondarenko, 2004).

\subsubsection{Tenvel unit}

This terrigenous and volcanic unit is composed of rhythmically alternating siltstone, polymict sandstone, and graywacke. Some horizons consist of turbidites. Among the terrigenous rocks, encountered are pillow basalts, picritic basalts, as well as tuffs and tuffites of mafic composition and variable grain size. Geochemical analysis suggests that the picritic basalts formed in a suprasubduction zone setting that was undergoing extension (Sokolov et al., 2002). The coarsening of the turbidite strata and the abundant volcanic clasts suggest that these deposits were derived from an arc and were deposited in a proximal forearc setting. Faunal remains in the siltstones yield Late Kimmeridgian-Early Tithonian ages (Shekhovtsov and Glotov, 2001).

\subsubsection{South Gremuchinsky unit}

This unit is developed in the catchment area of the Bystryanka River and in the upper reaches of the Orlovka and Uyamkanda Rivers (Fig. 3). It is composed of both chaotic and coherent tuffaceous clastic rocks, including turbidites. The chaotic horizons, consisting of matrix and clasts, are discriminated into terrigenous melanges of tectonic and submarine slump origin (olistostrome). Not infrequently, the rocks are heavily deformed and turned to zones of cataclasis. In such cases, their primary tectonic or sedimentary origin cannot be established.

The olistoliths and blocks of various sizes (from 1 to $50 \mathrm{~m}$ ) are composed of basalt, andesite, chert, gabbroids, and plagiogranite. The volcanic rocks comprise both MORB-like basalts and medium-Ti, high-Al tholeiitic basalts, andesites, and andesitic dacites of island-arc affinity. Some of the basalts and cherts resemble those of the Bystryanka unit described below, while the gabbro and plagiogranite are similar to those of the Vurguveem ophiolite. Cherts from the olistoliths contain the radiolarians Sethocapsa cetia Foreman, Stichocapsa aff. robusta Matsuoka, Hsuum cuestaense Pessagno, Mirifusue? sp., Ristola? cf. turpicula Pessagno and Whalen, Obesacapsula rotunda (Hinde), indicative of Oxfordian-Kimmeridgian age (V. S. Vishnevskaya, personal communication, 2000, GIN RAS, Moscow).

Some tectonic slices of the tuffaceous rocks and turbidites yield Oxfordian-Volgian and Berriasian-Valanginian faunas (Radziwill and Radziwill, 1975; Shekhovtsov and Glotov, 2001). Similar lithologies are found in the matrix of the melange as well. This suggests a Late Jurassic-Valanginian age for the matrix.

The presence of tuffaceous turbidites, terrigenous melange, and olistostromes with inclusions of oceanic rocks, gabbros, plagiogranites, products of synchronous island arc volcanism, as well as structural features (accretionary melange, C-S tectonites, broken formation, block-in-matrix structures, etc.) suggest formation of this complex within an accretionary prism.

\subsubsection{Bystryanka unit}

This siliceous and basalt unit is encountered in the southeastern part of the catchment area of the Bystryanka River and on the Polyarny uplift (Fig. 3). This unit is composed of deformed and variably altered basalts including greenschists, and of red radiolarian cherts. There are also flow units with pillow parting and interpillow lenses of carbonate and siliceous material.

Geochemically, the basalts and diabases are similar to oceanic or backarc basalts (Natal'in, 1984; Lychagin et al., 1991; Bondarenko, 2004). The cherts yield the radiolaria: (i) Haliodictya cf. Hojnosi Riedel et Sanfilippo, Stichocapsa convexa Yao, Williriedellum sp., Zhamoidellum sp., typical Bajocian-Kimmeridgian faunas (N. Yu. Bragin, personal communication, 2001, GIN RAS, Moscow); (ii) Parvicingula ex gr. schoolhousensis Pess. and Whalen, Stichocapca cjnvexa Yao, S. cf. japonica, indicating BathonianCallovian age (according to V. S. Vishnevskaya, Geological Institute, Russian Academy of Sciences, Moscow); and (iii) Amphipyndax aff. tsunoensis Aita, Stichocapsa cf. robusta Matsuoka, Hauum stenlfensis Pessagno, pointing to Callovian-Oxfordian age (V. S. Vishnevskaya, personal 
communication, 2000, GIN RAS, Moscow). Ged'ko et al. (1991) reports occurrences of Early Jurassic radiolarians.

\subsubsection{Merzlyui unit}

The Merzlyui unit is a dismembered ophiolite complex. Among thrust sheets, fragments of ophiolites are encountered: serpentinized ultramafics, gabbro, diabase dikes and sills, pillow basalts, red, black, and gray cherts containing small poorly preserved radiolarians and metamorphic rocks (greenschists, amphibolites, and garnet amphibolites).

According to Bondarenko (2004), in tectonic klippen found in the upper Uyamkanda River (Merzly Creek), ophiolite fragments are thrust northward onto terrigenous mélange. The terrigenous mélange contains also ophiolitic blocks a few meters to several dozens of meters across. Structurally lower, faulted and folded turbidites of Triassic age (Ustieva unit) and Jurassic-Lower Cretaceous age (Flysch unit) occur. The entire pile is unconformably overlain by coarse clastic deposits of Hauterivian-Barremian age containing clasts derived from ophioltes..

At the base of the ophiolite klippen, there are lenticular bodies of amphibolite and greenschist. Some of the major klippen have preserved the following rock succession (in ascending order): basalts and cherts, diabase dikes, gabbro, layered complex rocks, and serpentinized ultramafics. Apparently, the ophiolite sequence is overturned and metamorphosed.

The ophiolite assemblage was considered as either Late Mesozoic (Pinus and Sterligova, 1973) or Paleozoic (Ged'ko et al., 1991). The siliceous rocks contain some small unidentifiable radiolarians. Gray or black cherts are not typical of Late Mesozoic accreted complexes of NE Russia, (Grigoriev et all., 1994; Vishnevskaya, 2001) and so the origin of this unit is unclear. ${ }^{40} \mathrm{Ar} /{ }^{39} \mathrm{Ar}$ ages of amphibole and white mica from metamorphosed ophiolite fragments ranging from $257 \mathrm{Ma}$ to $229 \mathrm{Ma}$ (samples 00-8-A, M02-53/3, M02-53/5, and M02-56/8, Table 1; Fig. 2) support a late Paleozoic age for this unit. A whole rock integrated age of 124.2 $\pm 1.5 \mathrm{Ma}$ from sample M02-56/1 again reflects the mid Cretaceous overprint seen elsewhere (Natal'in, 1984; Parfenov, 1984; Zonenshain et al., 1990; Lychagin et al., 1991; Sokolov et al., 1997, 2002; Shekhovtsov and Glotov, 2001; Bondarenko, 2004).

\subsubsection{Penvel'veem unit}

This assemblage of terrigenous, tuffaceous, and volcanic rocks is located in the eastern part of the South Anyui terrane, in the catchment area of the Penvelveem River (Fig. 3). The underlying autochthonous unit is composed of turbidites resembling the Triassic deposits of the SAS and the cover of the Chukotka microcontinent.

On the Penvelveem uplift, this allochthonous unit consists of two parts, bounded by north-vergent thrusts (Figs. 4 and
5). The upper part of the allochthonous unit is an antiform whose flanks are composed of Jurassic-Valanginian rocks, and the core of Late Triassic terrigenous and volcanic deposits, typical of island arc sections of the Yarakvaam terrane in the Alazeya-Oloy foldbelt (Shekhovtsov and Glotov, 2001; Bondarenko, 2004). The Upper Triassic, Jurassic, and Valanginian deposits contain a variety of faunas.

The lower part of the Penvelveem unit consists of slices composed of siliceous rocks and basalts, as well as turbidites similar to the Gremuchinsky unit. Higher up, gabbro, plagiogranite, and greenschists occur. The gabbro and plagiogranite resemble those of the Paleozoic Vurguveyem ophiolite, located at the boundary of the SAS and the Yarakvaam terrane (Fig. 3). We dated whole-rock greenschists from samples 98116/2, 98117, 98117/3, 98117/6 (Table 1; Fig. 2). Interpreted ages range from $106 \pm 3$ to $119 \pm 4 \mathrm{Ma}$ (Fig. 2) reflecting the time of this Early Cretaceous metamorphism (as was also seen in the Vurguveem subterrane).

\section{The Yarakvaam terrane}

Located along the southeastern boundary of the SAS, the Yarakvaam terrane comprises part of the Alazeya-Oloy foldand-thrust belt (Parfenov et al., 1993; Nokleberg et al., 1994). This terrane is composed of sedimentary and volcanic rocks of island arc affinity of Upper Paleozoic-Lower Cretaceous age (Til'man et al., 1977; Parfenov, 1984; Parfenov et al., 1993) and of the Vurguveem and Aluchin ophiolites.

The island arc section begins with Lower Carboniferous strata (Shekhovtsov and Glotov, 2001). The Upper Triassic strata contain Tethyan fauna which differ dramatically from the Triassic faunas of the Chukotka microcontinent and instead resemble the faunas from the Velmai terrane located $800 \mathrm{~km}$ to the east (Tynankergav and Bychkov, 1987; Bychkov and Solov'yov, 1992).

The Vurguveem peridotite-gabbro massif (Gromadnensky terrane after Parfenov et al., 1993; Nokleberg et al., 1994; Gromadnensky-Vurguveem massif after Natal'in, 1984) is dominated by layered gabbro and gabbro-norite with subordinate amounts of troctolite, olivine gabbro, and lenticular bodies of peridotite (Ganelin and Silantyev, 2004). In the western part of the massif, there are plagiogranite bodies. The rocks are metamorphosed to greenschist facies and, in places, to amphibolite facies.

$\mathrm{K} / \mathrm{Ar}$ ages of the plagiogranite range from $150 \mathrm{Ma}$ to $252 \mathrm{Ma}$ (Palymskyi, 1966; Shekhovtsov and Glotov, 2001). Secondary low-K hornblende from the gabbro has a ${ }^{40} \mathrm{Ar} /{ }^{39} \mathrm{Ar}$ plateau age of $304.9 \pm 13.6 \mathrm{Ma}$ (sample GK-983-4, Table 1; Fig. 2) while a similar ${ }^{40} \mathrm{Ar} /{ }^{39} \mathrm{Ar}$ age of $332 \mathrm{Ma}$ was obtained from plagiogranite bodies impregnated gabbro (Korago, 2000). The late Paleozoic age of the gabbro is corroborated by its stratigraphic contact with the overlying sedimentary and volcanic deposits of Upper Carboniferous-Permian age (Shekhovtsov and Glotov, 2001). 

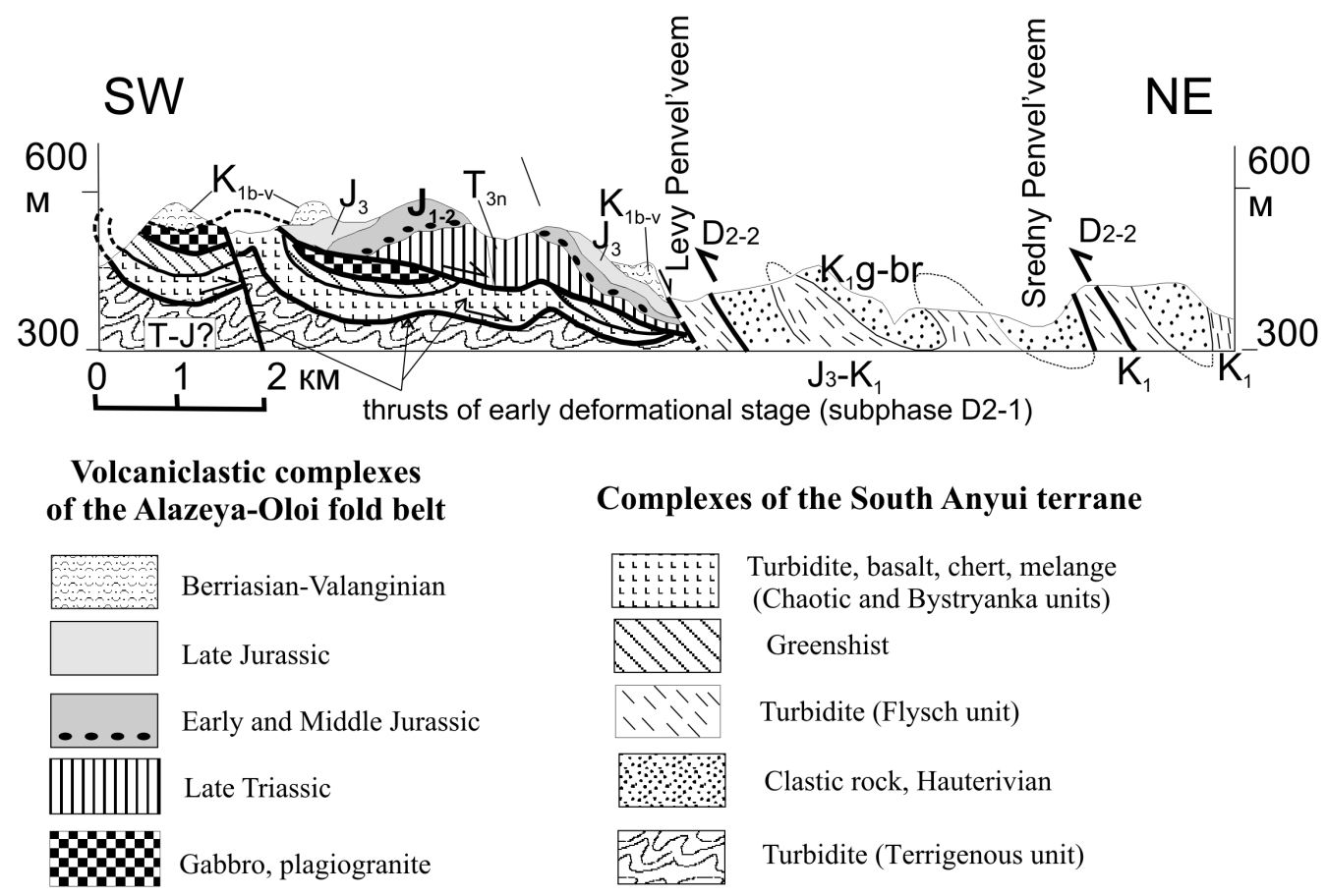

\section{Complexes of the South Anyui terrane}

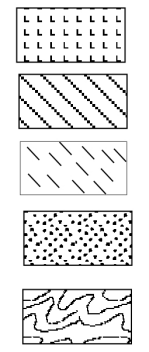

Turbidite, basalt, chert, melange

Greenshist

Turbidite (Flysch unit)

Clastic rock, Hauterivian

Turbidite (Terrigenous unit)

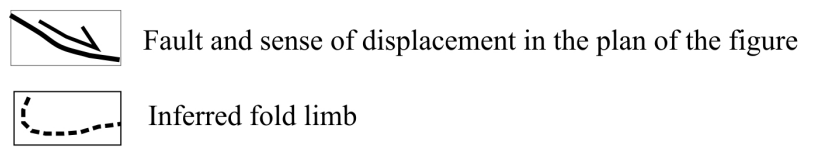

Fig. 5. Sketch profile across the Penvelveem uplift (see Fig. 3).

In the northern part of the Vurguveem subterrane, rocks of a sheeted dike complex cut through the gabbro and occupy a transitional position between the gabbro and upper Paleozoic volcanic rocks. The dikes are composed of diabase, gabbro-diabase, basalt, andesic basalt, andesite, and dacite. They strike approximately north-south and range from several centimeters to $3 \mathrm{~m}$ in thickness. The basalt dikes have negative $\mathrm{Ta}, \mathrm{Nb}, \mathrm{Ti}$, and $\mathrm{Zr}$ anomalies, typical for island arc tholeiites (Ganelin and Silantyev, 2006).

The age of the dike complex is not constrained. ${ }^{40} \mathrm{Ar} /{ }^{39} \mathrm{Ar}$ geochronologic data from a whole-rock dike sample (C$2573 / 3$, Table 1; Fig. 2) has a plateau age of $112.6 \pm 2.2 \mathrm{Ma}$ and from an amphibole sample (C-2572/9) has an isochron age of 93.2 2 2.2. However, judging from the crosscutting field relationships, the dike complex is probably Late Paleozoic in age and the Early Cretaceous argon age reflect later metamorphic resetting due to an Early Cretaceous deformational event. Late Cretaceous age of sample C-2572/9 is hard to explain. Firstly, individual dikes from dike complex may have Late Cretaceous age contemporaneous to beginning of Okhotsk-Chukotka volcanic belt activity and low temperature green amphibole appearance is probably related to postmagmatic processes. Secondly, this Ar/Ar analysis is not so good because there is not plateau.
The peridotite-gabbro complex along with the siliceous and basalt association (Bystryanka unit) was previously interpreted as an ophiolite that was a fragment of oceanic crust of the Late Mesozoic South Anyui oceanic basin (Natal'in, 1984; Parfenov, 1984; Zonenshain et al., 1990). However, geochemical data (Ganelin and Silantyev, 2004) suggest formation of the gabbros of the Vurguveem subterrane in a suprasubduction setting. Mapping (Shekhovtsov and Glotov, 2001) and our new geochronologic data corroborate the temporal and genetic link between the peridotite-gabbro massif and island-arc sedimentary and volcanic series of the Yarakvaam terrane. The Vurguveem subterrane can be viewed as a fragment of crust of the lower part of an island arc.

The Aluchin subterrane is located along the western margin of the Yarakvaam terrane (Fig. 3) and is composed of ophiolites and sedimentary and volcanic rocks. The ophiolites consist of tectonized mantle ultramafics of duniteharzburgite composition, a layered mafic series, and a dike complex (Lychagin, 1985; Oxman et al., 2003). These units comprise a system of high angle thrust sheets, plunging eastward beneath the Upper Paleozoic sedimentary and volcanic rocks of island arc affinity. The ophiolites are disintegrated and commonly turned to melange. Alongside the ophiolites, tectonic blocks of volcanics, sedimentary and volcanic rocks, and glaucophane schists are common. 
The composition of the ophiolites is not yet understood. Lychagin (1985) proposed that the Aluchin ophiolite is of oceanic origin. New geochemical data (Ganelin and Silantyev, 2006) suggest formation of the ophiolites in a suprasubduction setting. Chemically, the sheeted dike complex corresponds to N-MORBs, and their decreased $\mathrm{Cr}$ and $\mathrm{Ni}$ abundances and REE pattern suggest the backarc basin (Oxman et al., 2003; Ganelin and Silantyev, 2006).

Different viewpoints exist concerning the age of the rocks. Ophiolite clasts are encountered in Upper Triassic conglomerate (Glotov, 1995), whose age constrains the time of amalgamation of the ophiolitic subterranes and formation of the Yarakvaam terrane. A magmatic amphibole plateau age of $226.6 \pm 10.5 \mathrm{Ma}$ (sample C-2546, Table 1; Fig 2) points to a Late Triassic age for the sheeted dikes. However, it cannot be precluded that the Aluchin ophiolites consist of ophiolitic fragments of different ages derived from a variety of geodynamic settings.

\section{Structural data}

The complex and diverse deformation structures of the South Anyui suture and its northern and southern surroundings (the Anyui-Chukotka and Alazeya-Oloy foldbelts, respectively) can be subdivided into three time periods: precollisional, collisional, and postcollisional.

\subsection{Precollisional deformations $\left(D_{1}\right)$}

\subsubsection{Deformation parageneses of Pre-Late Triassic age (subphase $D_{1-1}$ )}

The internal structure and deformational history of the Vurguveem ophiolite plutonic rocks is complicated. The gabbroic rocks show deformations of different ages (Natal'in, 1984; Bondarenko, 2004). There are isoclinal folds of magmatic layering, metamorphic foliation parallel to axial planes of these folds, and zones of ductile and brittle-ductile mylonites (or zones of "hot" tectonic flow), as well as brittle cataclasis zones.

The earliest deformation event is recorded by ductile mylonite zones of NNW strike (Fig. 6a, event I), which deform igneous banding. A later deformation event is related to the formation of crosscutting zones of brittle-ductile mylonites (Fig. 6a, event II). It is to these zones that locally developed metamorphic foliation is confined. Spatial orientation of brittle-ductile mylonite zones suggests that they took shape under NS compression (Fig. 6b). It is likely that these zones occur in structural paragenesis with the northwardoverturned isoclinal folds, into which the metamorphic foliation in the gabbro, as well as plagiogranite veins, are folded (Sokolov et al., 2002). Later on, brittle cataclasis zones evolved in the gabbro (Fig. 6a, event III).

Evidently, deformation structures of events I and II formed while the rocks were still hot enough to develop "hot" my-
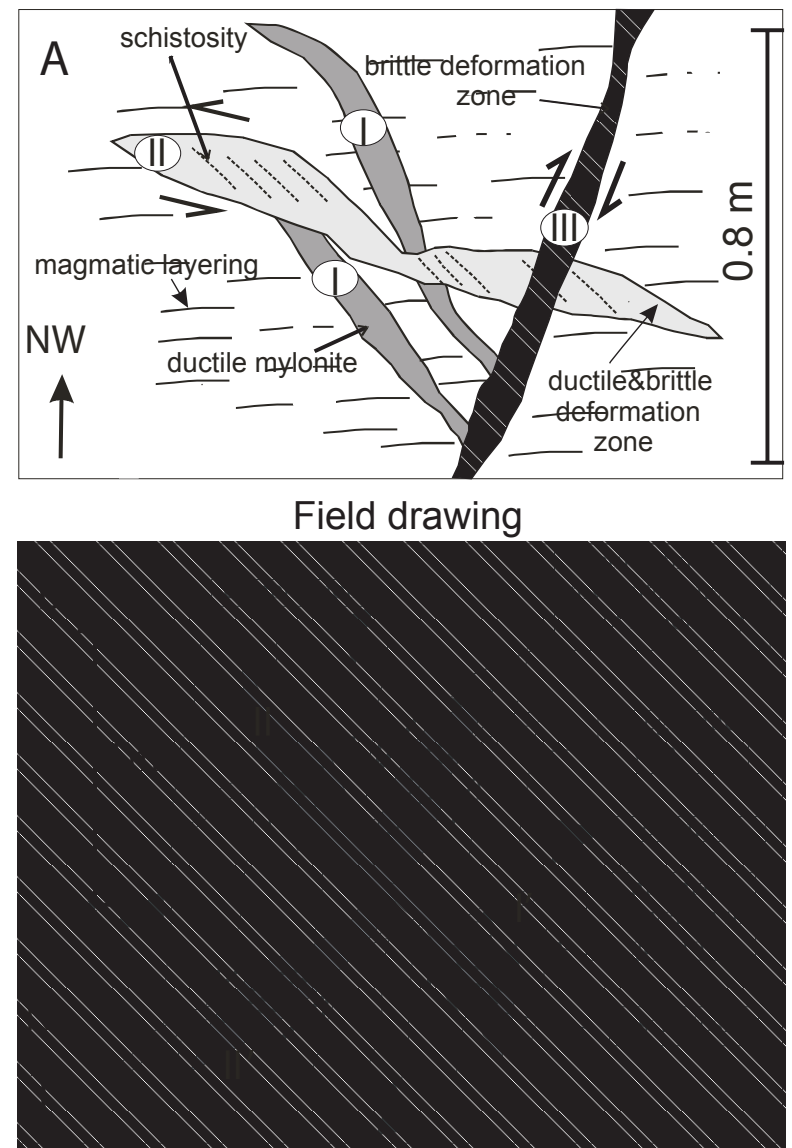

Field drawing

Fig. 6. Structural features resulting from several deformation events in the Vurguveem ophiolitic gabbro.

A - three phases of deformation in the same outcrop: I - the earliest ductile mylonite ("hot" mylonite), II - later brittle-ductile tectonite, III - brittle shear zone.

B - two phases of deformation in the same outcrop: I' - early extension fractures filled with pegmatite veins, II' - later ductile mylonite zones. It appears that structural features II in Fig. A and structural features II' in figure result from the same deformation phase.

lonite structures (Sokolov et al., 2002). Stage I was followed by emplacement of plagiogranite and related pegmatite veins. The plagiogranite is Late Paleozoic in age (K\Ar method, Palymskyi, 1966; Shekhovtsov and Glotov, 2001), and its chemical signature suggests island-arc affinity (Shekhovtsov and Glotov, 2001; Sokolov et al., 2002). Consequently, the closely coeval events I and probably II took place in an island arc prior to its accretion. Cataclasis zones (event III) likely formed during accretion of the island arc or at the postcollisional stage. The timing of amalgamation of the Vurguveem and Aluchin ophiolites into the Yarakvaam terrane is constrained by the finds of ophiolitic pebbles in Upper Triassic conglomerate. 


\subsubsection{Deformation parageneses of Late Triassic age (subphase $D_{1-2}$ )}

Deformation parageneses of Late Triassic age (subphase $\left.D_{1-2}\right)$ are recorded in the Upper Triassic terrigenous complex of the SAS in the catchment area of the Yarakvaam River, as well as in the southern part of the AnyuiChukotka foldbelt (Chukotka microcontinent) in bluffs along the Keperveyem River in the town of Bilibino (Fig. 3).

In the catchment area of the Yarakvaam River, turbidites display prefolding normal faults. Their fault planes dip in the same direction as the bedding (Fig. 7). Clastic transport direction was from north to south. Apparent throw on the normal faults reach a few meters (Fig. 7, right down box). These normal faults took place during the process of sedimentation and can be viewed as syndepositional because we can see it's influence onto thickness of sandstone layers (Fig. 7, right down box).

In riverside bluffs of the Keperveyem River, Upper Triassic deposits of the Chukotka microcontinent contain turbidite members up to several dozens of meters thick. The turbidites consist of coarse rhythmic alternation of sandstone, siltstone, and less frequently, silty mudstone. In the turbidites, two phases of normal faulting of different ages are distinguished (Fig. 8). The early small displacement faults are confined to bedding planes (Fig. 8a). The bedding plane shears resemble similar to S-C structures (Fig. 8a), as well as en echelon tensile zones of the pull apart type (Fig. 8b). The latest normal faulting produced top-to-the-south brittle fractures ranges from several millimeters to several dozens of centimeters (Fig. 8; drawing of outcrop).

The level of metamorphism in the rocks does not exceed the prehnite-pumpelliite facies, which precludes ductile deformations. Consequently, it can be assumed that the early normal faults formed in poorly lithified sediments at a passive continental margin. The sense of the bedding plane shears is consistent with the direction of sediment transport and the orientation of submarine slump textures in the turbidites.

\subsubsection{Deformation parageneses of Early Jurassic age (subphase $D_{1-3}$ )}

The Triassic deposits of the Chukotka microcontinent display several phases of deformation. The earliest of these are the metamorphic foliation $S_{1-0}$, roughly parallel to bedding $S_{0}$ (Fig. 9), as well as boudinage structures. Boudinage is developed with asymmetric lenticular boudins composed of sandstone and quartz veins. The ratio of the length of boudins to the gaps between them reaches 1:1.5. This suggests a high degree of deformation.

The metamorphic foliation is folded into isoclinal folds (Fig. 9b and c). Fragments of hinges of these folds are involved in later deformations. The axial plane cleavage $S_{1}$ of these folds produced by later collisional deformational event
$\left(D_{2}\right)$ cuts the metamorphic foliation, and it is itself deformed (Fig. 9a and b).

Flakes of white micas are confined both to the surfaces of the early metamorphic foliation $S_{1-0}$ and of the slaty axial plane cleavage $S_{1}$. In thin-sections, it can be seen that micas are located on the surfaces older than $S_{1}$. Micas are deformed as a result of differential movements along $S_{1}$ cleavage planes. These deformations along the surfaces older than $S_{1}$ were likely zones of bedding plane slip and crosscutting normal faults. The age of the normal faulting and postdepositional transformations is constrained by the micas and clay minerals at 200-204 Ma (K-Ar and Rb-Sr methods, Tuchkova et al., 2007). We suppose that pre- $S_{1}$ normal faulting was related with Early Jurassic extension tectonic event.

\subsubsection{Deformation parageneses of Jurassic-Early Cretaceous age (subphase $D_{1-4}$ )}

Deformation parageneses of Jurassic-Early Cretaceous age (subphase $D_{1-4}$ ) are widespread in the South Anyui suture; they consist of tight appressed folds, cleavage, metamorphic foliation, C-S mylonites, and boudinage. In the Southern Gremuchinsky, Bystryansky, Terrigenous, and Flysh complexes, mélanges of the "dismembered formation" and "broken formation" types have been identified and described (Sokolov et al., 2002; Bondarenko, 2004); these are common in terrigenous mélanges of accretionary prisms (Cowan, 1985).

Mélanges of the "broken formation" type are featured by broad occurrence of boudinage, although primary stratification can still be restored. In "dismembered formation" type mélanges, primary stratification is no longer discernible (Fig. 9a). In the tectonized shale matrix, C-S mylonite ductile fabrics are common. They provide a good kinematic indicator, suggesting a south to north direction of tectonic transport (in the geographic reference frame). Unfortunately, we did not date the $D_{1-4}$ deformational stage, but structures of the $D_{1-4}$ deformation are cut by faults of $D_{2}$ deformational stage.

\section{Collisional deformations $\left(D_{2}\right)$}

In the collisional deformation history, we recognize two principal phases of different age: (i) early deformation, associated with the formation of the thrust structures and (ii) late deformation, associated with the formation of compressional dextral strike slip structures (Sokolov et al., 2002, Bondarenko, 2004).

\subsubsection{Structural parageneses associated with the forma- tion of the thrust structure (subphase $D_{2-1}$ )}

Thrust deformations are best expressed on the Polyarny and Penvel'veem uplifts of the SAS, as well as in the sources of the Angarka River, where folded and faulted allochthonous thrust sheets have been established (Fig. 3). 


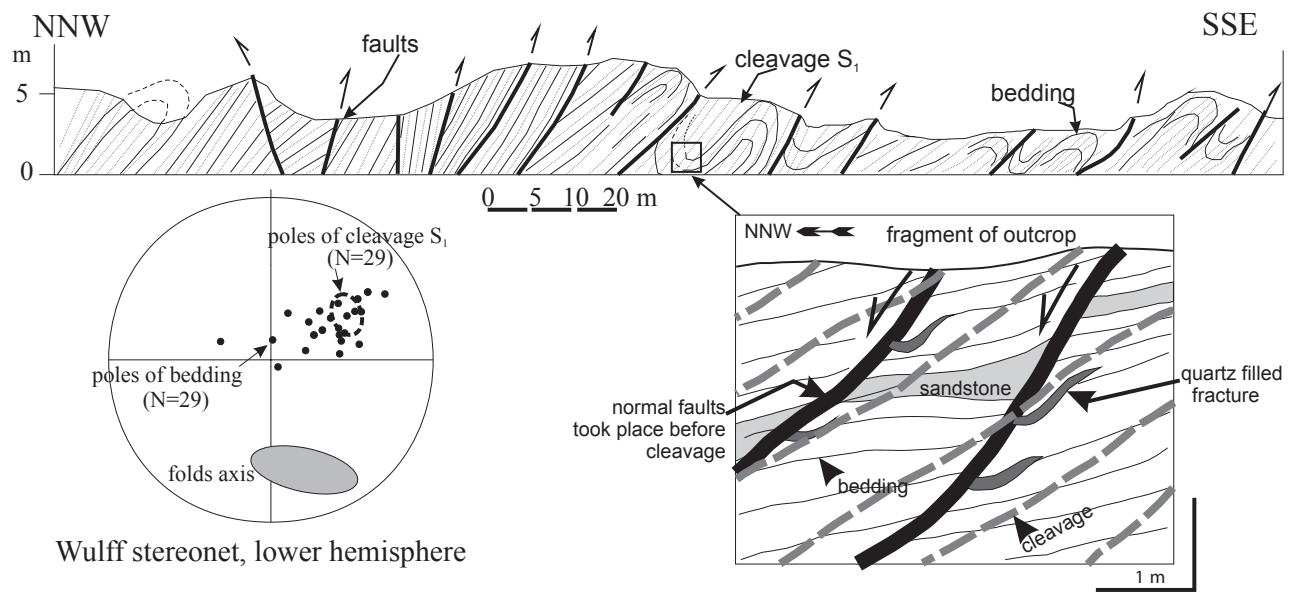

Fig. 7. Riverside bluffs in the source area of the Yarakvaam River, SAS. Syndepositional normal faults in the terrigenous complex (Ustieva unit). Syndepositional character of the normal faults is emphasized by the systematic increase in the thickness of sandstone beds. The faults are oriented in the same direction as the transport of clastic material during accumulation of the sequence.
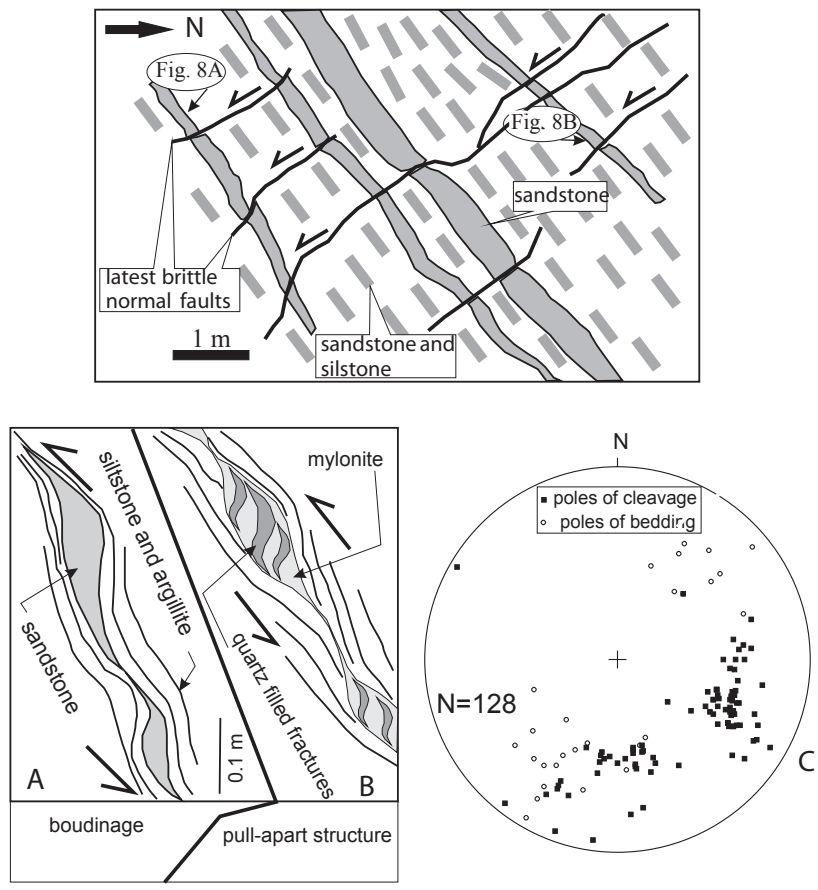

Fig. 8. Keperveem River, Bilibino city. Two generations of faults of different ages in Upper Triassic turbidite unit of the Chukotka microcontinent. Drawing from photograph and outcrop. This domain has been clockwise rotated around the horizontal axis.

A and B - early bedding-plane faults. The character of deformation suggests that faulting took place prior to complete lithification on the deposits. Black lines on the drawing of photograph indicate late normal faults. C - Wulff stereonet, lower hemisphere. Bedding and cleavage are secondary deformed.

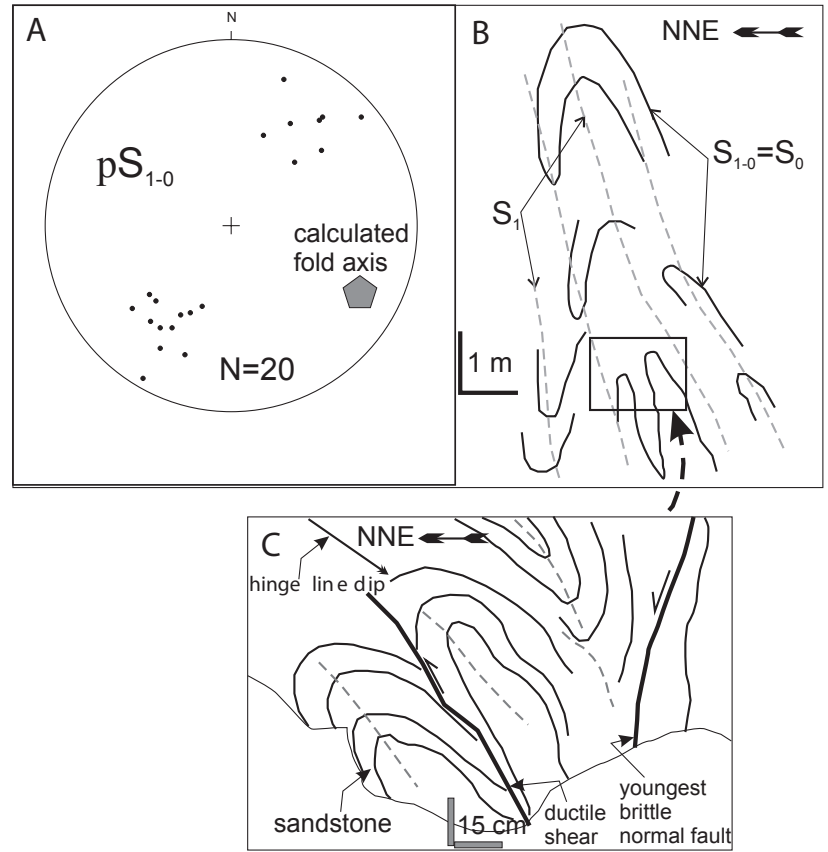

Fig. 9. Upper Triassic turbidites of the Chukotka microcontinent in riverside bluffs on the right side of the Malyi Anyui River, $28 \mathrm{~km}$ south of Bilibino.

A - Lower hemisphere, Wulff stereonet Poles of metamorphic schistosity $S_{1-0}$.

B and C - Metamorphic $\left(S_{1-0}\right)$ foliation of Early Jurassic age, folded into appressed synthrusting folds in the course of later deformation events. The metamorphic foliation is roughly parallel to the bedding $\left(S_{0}\right)$. Metamorphic foliation and bedding are crosscut by axial plane cleavage $\left(S_{1}\right)$. 
On the Penvel'veem uplift, the footwall consists of Triassic rocks of the Ustieva unit (Figs. 4 and 5). The hanging wall is composed of gabbro, ultramafic rocks, greenschists, and a fragment of the Triassic-Valanginian stratigraphy of the Yarakvaam terrane. This fragment is composed of volcanic rocks, tuff, and clastic rocks, as well as Upper Jurassic-Lower Cretaceous turbidites and terrigenous rocks of the SAS. On the Penvel'veem uplift, south vergent structures clearly overprint the earlier north vergent features.

In the sources of the Angarka River, the lower structural unit (autochthon) is composed of Upper Triassic terrigenous rocks (Ustieva unit), which is overlain by Upper JurassicLower Cretaceous turbidites (Flysch unit) and island-arc sedimentary and volcanic rocks (Kul'polney unit) of the SAS (Fig. 10). In the vicinity of Mt. Dvuglavaya, a major synform is composed of disintegrated ophiolites with serpentinite mélange at the base (Fig. 10). In the valley of the Glubokaya River, there is a tectonic block of Upper Triassic tuffaceous sedimentary rocks similar to the deposits of the Yarakvaam and Oloy terranes. The Upper Triassic rocks are overlain by island-arc Upper Jurassic-Lower Cretaceous sedimentary and volcanic rocks (Kul'polney unit) with an angular unconformity and a horizon of coarse clastic rocks at the base. The nappe structure is overlain with angular unconformity by effusives of Albian-Cenomanian age, which are part of the Okhotsk-Chukotka volcanic belt. This mid Cretaceous volcanic rocks are cut by strike-slip and normal faults but not cut by thrust faults.

Structural features associated with thrusting are recorded in the Upper Jurassic-Lower Cretaceous deposits of the South Anyui suture (Fig. 11a) and the Triassic deposits of the Anyui-Chukotka fold system (Fig. 11b and c). In terrigenous rocks, one finds tight isoclinal folds overturned to the north, in which pervasive cleavage is well expressed, parallel to their axial planes. Fold axes are commonly low angle and strike roughly EW (Fig. 11b, left stereogram). Undulations of the axes of such folds are associated with later strike-slip deformations as will be shown below (Sokolov et al., 2001).

In tectonic mélange zones, rotation of boudins is recorded, as well as rotation of the detached fold hinges (foldsboudins) about low angle roughly EW trending axes (Fig. 11a and b, right hand parts of the diagram). This suggests northward tectonic transport of thrust masses. Synthrusting rotation of sandstone boudins is expressed in the form of direct rotation of structures (Fig. 11b, right hand part of the diagram), as well as reverse rotation structures (Fig. 11c). The reverse sense of rotation of boudins was due to motions along cleavage $S_{1}$ planes, as well as along R-joints.

Orientation of the long axes of boudins, cleavage-bedding intersection lineations and fold axes in the South Anyui suture and in adjacent structures of the Anyui-Chukotka fold system shows that thrust-related linear structural features are oriented at low angle and mostly trend roughly East-West (Fig. 12). Departures in the orientation of these linear struc- tural features are due to the impact of later strike-slip deformation and rotation. As a result of overprinted strike-slip deformations, synthrusting linear features are re-oriented in space. On stereograms, this is recorded by continuous belts of points (Fig. 12a, b, c, d, and f). In case of minor impact from overprinted strike-slip deformations, stereograms show discontinuous belts of points (Fig. 12e).

Good kinematic indicators are provided by oblique fabrics with lenticular boudins, widespread in thrust zones. Long axes of these boudins are oriented at low angle and roughly parallel to the axes of synthrusting folds. Similar to the "broken" or "dismembered" formation mélanges (Fig. 11b, right down box) may start it's forming during Late Jurassic to Early Cretaceous time (subphase $D_{1-4}$ ).

\subsubsection{South vergent structures (subphase $D_{2-2}$ )}

North vergent thrusts and tectonic nappes in the South Anyui suture are modified by opposite, south vergent structural features: reverse faults, thrusts, and bedding folds with axial plane cleavage (Figs. 5 and 13).

In the lower reaches of the Uyamkanda River, riverside bluffs display heavily deformed thinly rhythmic turbidites of Triassic age, containing mudstone members. The thickness of fine clastic members ranges along strike from a few meters to a few dozens of meters. With their increasing thickness, deformation degree increases. Detailed observations on the relationships of bedding and cleavage suggests the presence of a package of overturned isoclinal folds. Cleavagebedding intersection lineation has trends ranging from 90 to 135 , plunging less than $20^{\circ}$. In a number of places, fragments of hinges of isoclinal folds (Fig. 13) are preserved. The thickness of mudstone increases near the hinges of isoclinal folds as a result of plastic flow of clay matter.

In the Triassic deposits of the Anyui-Chukotka fold system, one finds (see above) packages of north vergent isoclinal folds of the phase $D_{2-1}$, into which the bedding, early metamorphic foliation, and the early axial plane cleavage $S_{1}$ are folded. Figure 14 shows that these folds were refolded in the process of formation of the opposite (south) vergent structural features. In this exposure, structural features also show evidence of later strike-slip related deformations. We attribute, south vergent tectonic deformations to two causes: (i) formation of backthrusts, common in areas with thrust tectonics, and (ii) impact from later motions along strike-slip faults (Sokolov et al., 2001, 2002; Bondarenko, 2004).

It is clear that not all the constituents of the fold-and-thrust structure of the collisional phase of deformations took shape simultaneously. The earliest structural features are bedding plane shears and schistosity, and the cleavage $S_{1-0}$. Somewhat later, synthrusting isoclinal folds took shape. These folds involve zones of the earlier bedding plane shears. Later on, isoclinal folds were folded and faulted, giving rise to both north- and south-vergent plunging isoclinal folds. Back- 

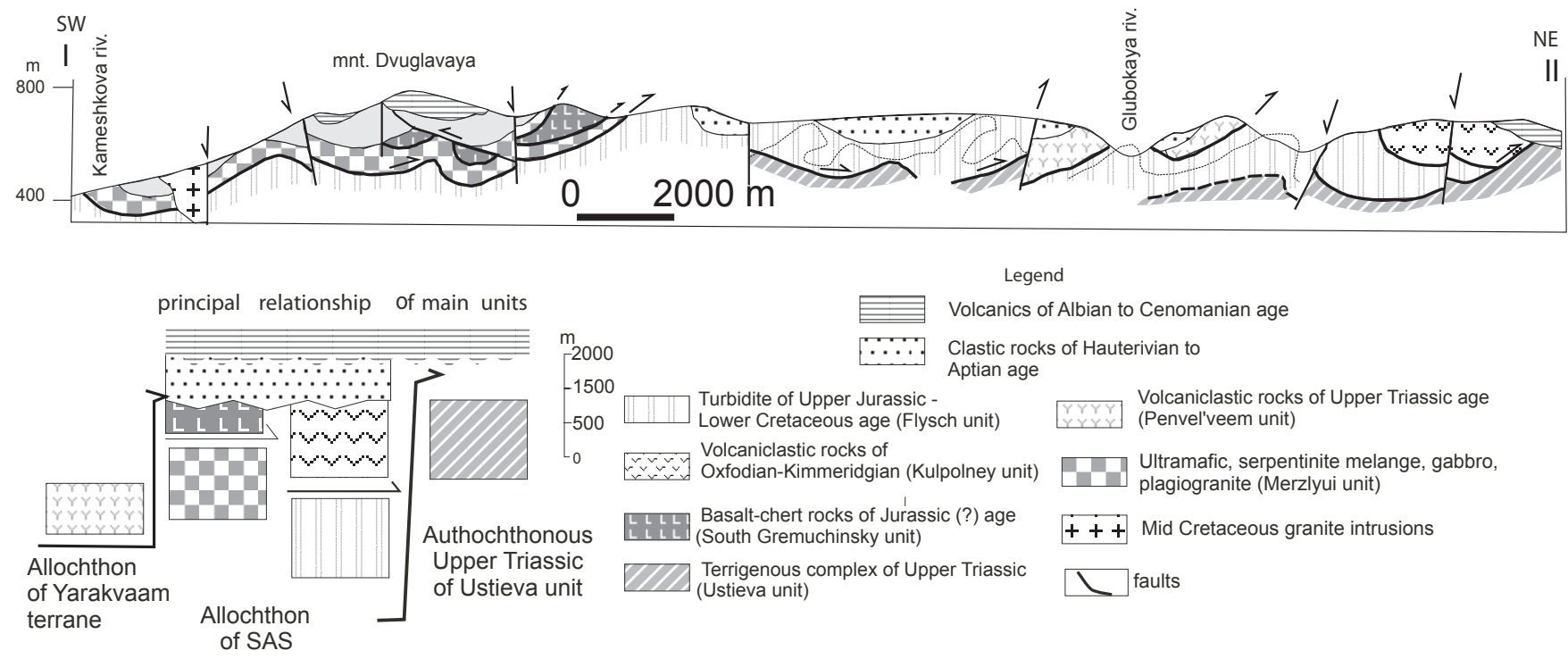

Fig. 10. Geological profile along the line mnt. Dvuglavaya-Glubokaya River across the fold-and-thrust structure of SAZ. Place of profile shown on Fig. 3.

thrusts and their conjugate fold features terminate the phase of formation of the fold-and-thrust pile.

\subsubsection{Late collisional strike-slip structural parageneses (subphase $D_{2-3}$ )}

Fold-and-thrust structure of the SAS, as well as adjacent parts of the Anyui-Chukotka foldbelt, are modified by a system of WNW trending strike-slip faults (Sokolov et al., 2001, 2002; Bondarenko, 2004). The first data on the presence of strike-slip features in the region were furnished by $\mathrm{Na}$ tal'in (1984), and Parfenov (1984).

Strike-slip faults were identified from zones of nearly vertical cleavage, extensive development of folds with nearly vertical hinges, boudinage with nearly upright long axes, and duplex structures that are Z-shaped in plan view. Strike-slip deformation commonly leads to the formation of a system of nearly vertical tectonic slices, as well as south vergent features (Sokolov et al., 2002; Bondarenko, 2004). In a number of localities dextral strike-slip structures also have a compressional constituent, giving rise to flower structures, as, for example along the northern boundary of the Yarakvaam terrane (Fig. 3).

Strike-slip deformation can be illustrated by several spectacular cases. The Vurguveem massif is Z-shaped in plan view (Natal'in, 1984) due to a roughly EW-trending dextral strike slip, which is recorded at different scales of observation. The central part of the massif underwent clockwise rotation about a nearly vertical axis (Sokolov et al., 2002, Fig. 5b)
The terrigenous deposits of the Ustieva and Flysh units commonly display dextral strike-slip ductile and brittleductile deformation features. They contain lenticular boudins with upright long axes (Fig. 14a). These strike-slip faults deform the earlier structural features (cleavage, fold axes, etc.). This is clearly exemplified by undulations of hinges of the earlier synthrusting folds in the Upper Triassic deposits in the upper reaches of the Khrebtovaya River (Fig. 14b).

Judging by the observed displacements of geological markers, horizontal offset along some of the major dextral strike slip faults reaches a few dozens of kilometers (Sokolov et al., 2002). The best marker of dextral strike-slip faults displacement amplitude is the Vurguveem massif Z-shape structure. Dextral strike slip is at least $10 \mathrm{~km}$ (Natal'in, 1984; Sokolov et al., 2002).

Dextral strike-slip faults deform the coarse clastic deposits of Barremian-Aptian age, and do not deform upper Albian effusives of OCVB. For this reason, the time of postcollisional dextral strike slip motion may be constrained to the Barremian-Aptian (possibly, early Albian) interval.

\subsection{Postcollisional deformations $\left(D_{3}\right)$}

This phase of deformation is featured by EW trending brittle sinistral strike-slip faults, whose location may be inherited from preexisting fault planes. Sinistral strike-slip faulting is demonstrated by the local development of tight conical folds with nearly upright axes within zones of intense deformation up to a few dozen meters in thickness. The domains between these zones show only open folds of bedding and cleavage and widely spaced tension fractures. The sinistral strike-slip 

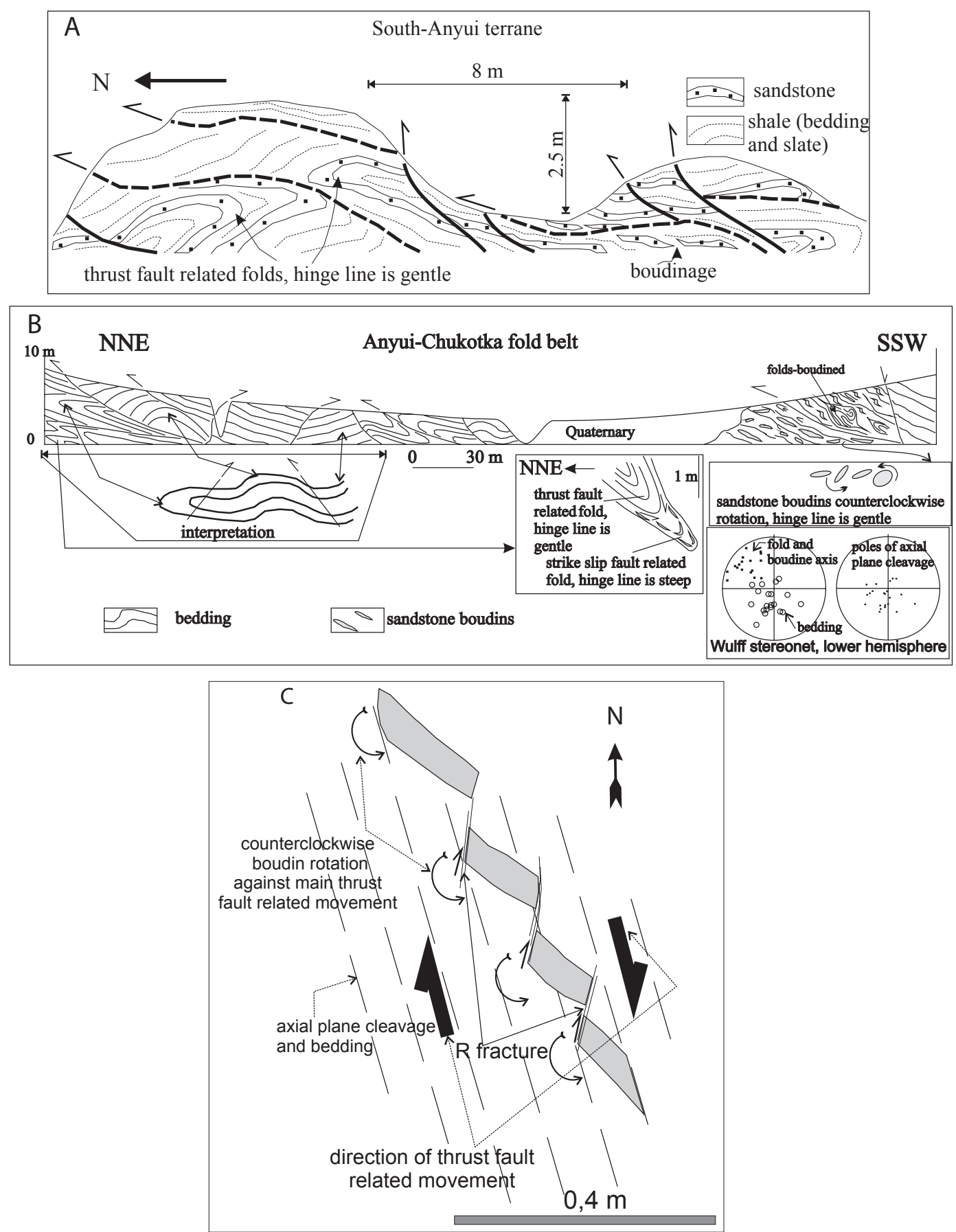

Fig. 11. Thrust-style deformations (subphase $D_{2-1}$ ) in terrigenous deposits of the Ustieva unit on the western side of the Khrebtovaya River, in the vicinity of the village of Stadukhino (A) and in Upper Triassic turbidites of the Chukotka microcontinent in the middle reaches of the Urguveem River (B, C). Stereograms show orientation of long axes of boudins from terrigenous mélange (left) and axial plane cleavage poles (right).

faults strike NNE-SSW and offset the Albian-Cenomanian rocks of the OCVB. These faults were accompanied by upper Upper Cretaceous dikes. Within certain areas, this system of faults controls the drainage network, and lozenge-shaped Quaternary depressions are confined to their intersection.

\section{Discussion and conclusions}

The tectonic history of the SAS can be divided into three major periods of deformation: precollisional, collisional, and postcollisional. 

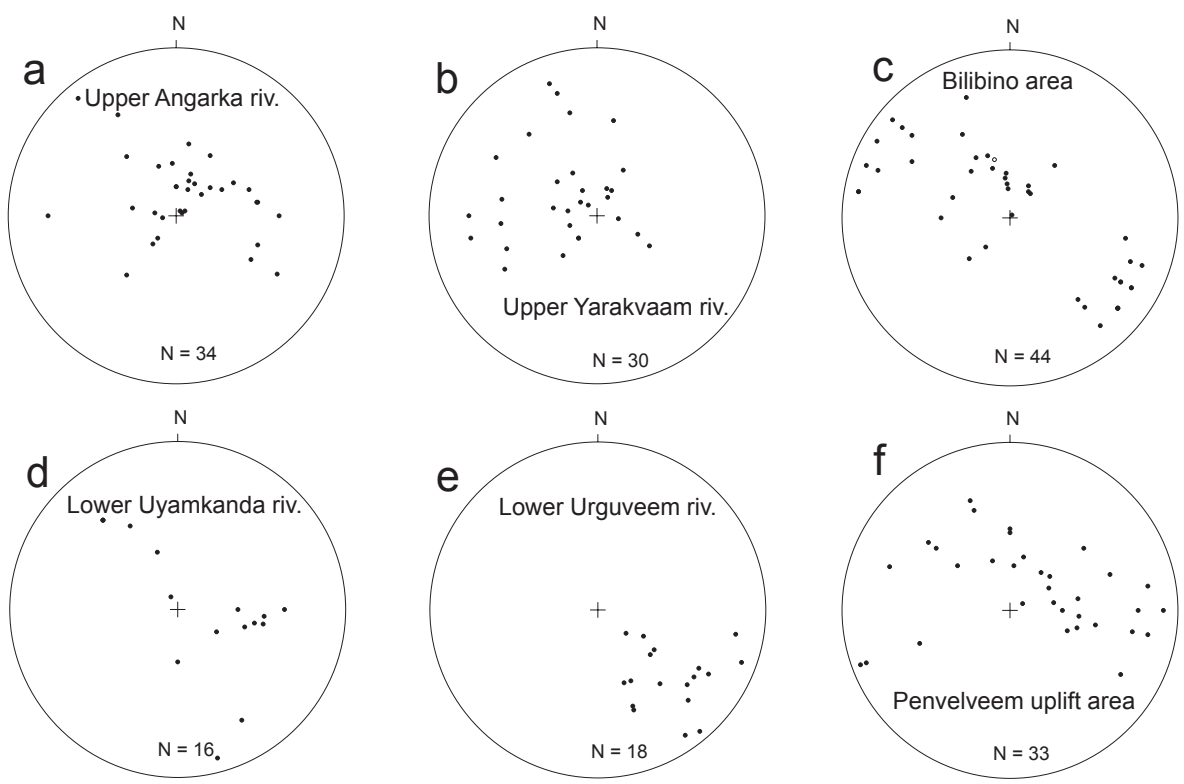

Fig. 12. Wulff net, lower hemisphere. Linear structural features associated with thrust faults (low angle) and with later strike-slip faults (high angle). Orientation of lineation (folds and boudins long axis, bedding-cleavage intersection) for 5 areas of SAS (a, b, d, e, f) and 1 area of Anyui-Chukotka folded zone (c). Full belts of dots (stereonets a, b, c, f) show results of thrust fault related deformation (gentle plunge), and later strike slip fault related secondary deformation (steep plunge, central parts of stereonets). Stereonet (e) illustrates low influence of secondary strike slip fault related deformation.

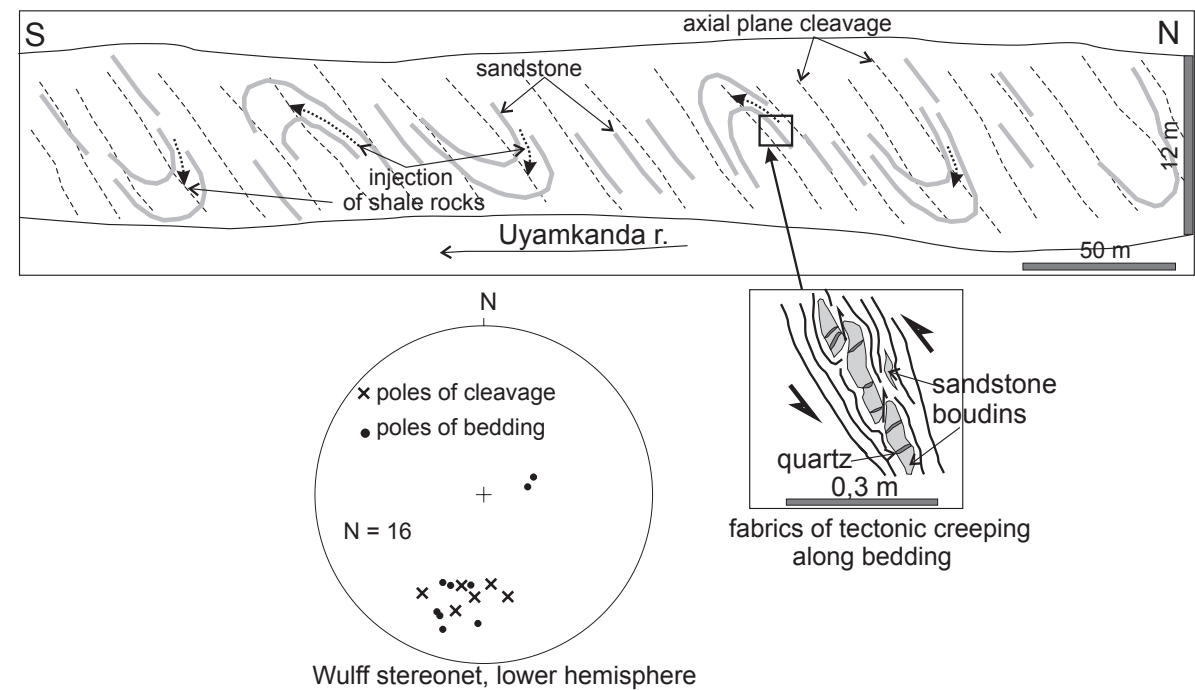

Fig. 13. Uyamkanda River. A reconstruction of south-vergent isoclinal folded structures in Triassic deposits of the Ustieva unit.

\subsection{Precollisional deformations}

Precollisional deformations encompass the time interval from the Late Paleozoic to the Middle Jurassic. The tectonic regime of that time was defined by the existence of a rather large Proto-Arctic ocean. In Early and Middle Paleozoic time, this oceanic basin was linked to the Uralian paleo-ocean to the west (Ruzhentsev and Aristov, 1998), whereas, in the east it incorporated the Anyui and Angayucham oceanic basins. The time of inception, initial history, dimensions, spatial position, and relationships of these basins remain unclear necessitating further studies of each particular basin and their comparative analysis, which would enable properly grounded paleotectonic and paleogeographic reconstructions. 

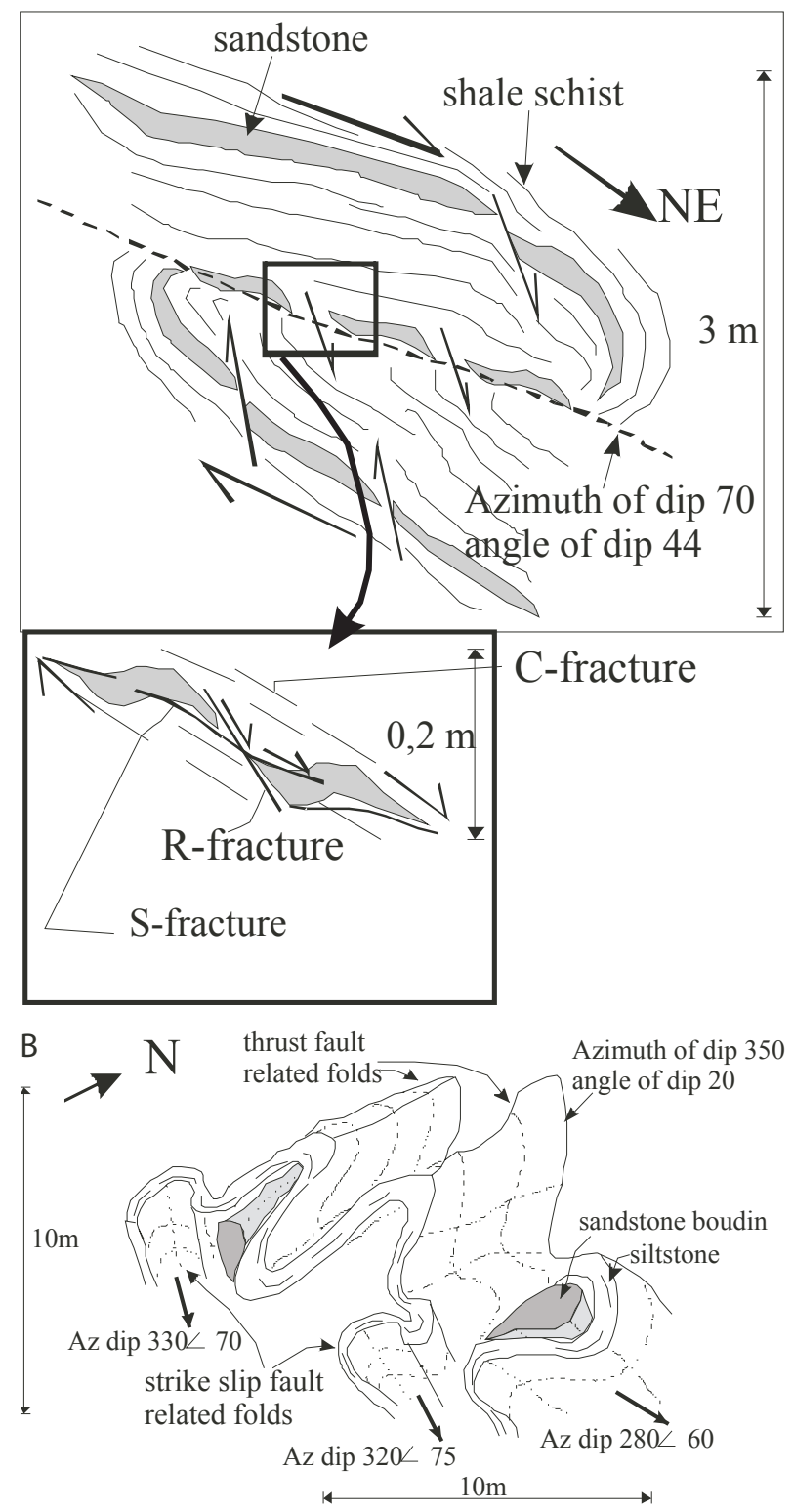

Fig. 14. Triassic turbidites (Ustieva unit). Structural features related to motions on dextral strike- slip faults trending WNW. Figure A depicts a strike-slip fault related fold with an upright hinge. Figure B portrays synthrusting folds with low angle hinges (axis trend 350 plunge 20) refolded through dextral strike-slip motions. As a result, orientations of fold axes (axis trend 280 plunge $60^{\circ}$, axis trend azimuth 320 plunge $75^{\circ}$, and axis trend azimuth 330 plunge $70^{\circ}$ ) and long axes of boudins changed.

The southern (in the present geographic reference frame) boundary of the Anyui oceanic basin where it bordered the North Asian continent was an active one. The age of the island arc complexes of the Yarakvaam terrane indicates that this oceanic basin already existed as early as the Carboniferous. Stratigraphic data on the age of sedimentary and volcanic rocks (Early Carboniferous-Neocomian) are now fur- ther supported by ${ }^{40} \mathrm{Ar} /{ }^{39} \mathrm{Ar}$ age determinations from the Vurguveem ophiolitic gabbro. The time of metamorphism, as defined on secondary hornblende, $304.9 \pm 13.6 \mathrm{Ma}$ (sample GK-983-4, Table 1; Fig. 2), agrees with the previously obtained age of gabbro intruded by plagiogranites, $332 \mathrm{Ma}$ (Ar/Ar method, Korago, 2000).

New radiometric and geochemical data (Ganelin and Silantyev, 2004) have important implications for the regional geology and tectonic concepts. First, the data are counter to the interpretation that the Vurguveem ophiolite was a fragment of Late Mesozoic oceanic crust cogenetic with the siliceous-and-volcanic association (Bystryanka unit) of the SAS (Radziwill and Radziwill, 1975; Parfenov, 1984; Natal'in, 1984; Chekhov, 2000). Second, the established temporal and genetic links between the gabbro and island arc complexes (the ancient subduction zone) are at odds with the idea that Proterozoic continental crust existed on the site of the Yarakvaam terrane (Til'man et al., 1975, 1977; Shapiro and Ganelin, 1988, Chekhov, 2000). In Late Paleozoic time, the Yarakvaam terrane was an oceanic island arc. Structural data (subphase $D_{1-1}$ ) indicates a southward dipping subduction zone (geographic reference frame), which agrees well with regional data.

The formation of the Yarakvaam terrane involved amalgamation of the Aluchin and Vurguveem subterranes, which must have been accompanied by deformation of the ophiolite complexes. The time of amalgamation is constrained by the Norian age of conglomerates containing ophiolitic pebbles (Glotov, 1995; Sokolov et al., 2002). This tectonic event was coeval to the formation of the dike and basalt complex, located in the western part of the Aluchin ophiolite. The Carnian (226.6 $\pm 10.5 \mathrm{Ma})$ age of the dikes and suprasubduction affinity of the pillow lavas and the sheeted dike complex point to the inception of a backarc basin. Consequently, both events might have been related to a tectonic rearrangement and emergence of a new convergent boundary.

The age of amphibolites encountered in the thrust sheets composed of oceanic crustal fragments (sample 00-8-a, $239.1 \pm 3.8 \mathrm{Ma}$; Fig. 2) or in tectonic blocks among terrigenous mélanges (229-257 Ma; samples M02-53/3, M02-53/5, M02-56/8) constrains the time of subduction processes or intraoceanic deformation. Geological data constraining the inception of the oceanic Kul'polney island arc (Sokolov et al., 2002) to the Oxfordian-Kimmeridgian (Schekhovtsov and Glotov, 2001) agree well with the age of greenschists (158.1 44.0 Ma, sample 9973/1, Table 1; Fig. 2), most likely originating from subduction. Deformations in the structure of the accretionary prism (subphase $D_{1-4}$ ) are dated as Late Jurassic-Early Cretaceous based on the age of inclusions and matrix (Sokolov et al., 2001, 2002).

The northern margin of the Anyui oceanic basin was a passive one. In Triassic time, terrigenous (including turbidite) sediments accumulated on the shelf and slope of the Chukotka microcontinent. Structural studies have established syndepositional normal faults $\left(D_{1-2}\right)$ with south- 
ward dipping planes, which is in keeping with the sedimentological data on the direction of clastic transport (Miller et al., 2006; Tuchkova et al., 2006). Evidence of contrasting vertical movements (subphase $D_{1-3}$ ) of Early Jurassic age (Tuchkova et al., 2007) makes it possible to explain the lack of Lower and Middle Jurassic deposits by a general uplift of the territory. The Bathonian-Oxfordian age of the chertand-basalt association (Bystryanka unit) constrains the time of termination of oceanic crust generation in the Anyui basin. The cessation of spreading was followed by a new stage: closure of the oceanic basin, marked by accumulation of terrigenous deposits (Flysch unit).

\subsection{Collisional deformations}

Collisional deformations took place in Early Cretaceous time in the course of closure of the oceanic basin due to collision of the active Asian margin and the Chukotka microcontinent, variously interpreted as a part of the North American continent (Parfenov, 1984; Nokleberg et al., 1994, 1998; Grantz et al., 1998), but also as a hypothetical Arctic continent (Zonenshain et al., 1990), a Hyperborean platform (Til'man et al., 1977; Seslavinsky, 1979; Ustritsky and Khramov, 1987), or the Bennet-Barovia block (Natal'in et al., 1999).

The collisional stage spanned a rather wide age range from the Neocomian to the Aptian (Parfenov, 1984; Natal'in, 1984; Sokolov et al., 2001, 2002). Structural studies have established the following time series of tectonic deformations: (i) north vergent thrusts and nappes (subphase $D_{2-1}$ ), (ii) south vergent thrusts and folds (subphase $D_{2-2}$ ), and (iii) late collisional dextral strike-slips (subphase $D_{2-3}$ ).

The North vergent thrusting took shape during the Hauterivian-Barremian (Sokolov et al., 2001, 2002), and the Aptian-Albian stage, in the course of which the Ainakhkurgen, Kameskov, and Nutesyn basins formed. These are filled in with slightly deformed sedimentary and volcanic deposits, overlapping with sharp angular unconformity all principal tectonic features of western Chukotka. Among the radiometric data (Table 1; Fig. 2), those corresponding to collisional events are: the age of greenschists (115-119 Ma, samples $98117,98117 \backslash 6$ ) pointing to deformation of the accretionary prism, and the age of secondary alterations in the mafic dikes (112 Ma, sample C-2573/3).

\subsection{Postcollisional deformations}

In Albian-Cenomanian time extension was predominant in the Chukotkan region (Miller and Hudson, 1991; Miller et al., 2002; Bondarenko, 2004). Extension was accompanied by normal faulting and the growth of Cordilleran type metamorphic core complexes (Bering Strait Geologic Field Party, 1997; Bondarenko and Luchitskaya, 2003). In the South Anyui suture, a system of roughly NS- and NW-trending transtensional faults emerged, described in Natal'in (1984) and Bondarenko (2004). These faults are often associ- ated with subalkaline dike swarms (Shekhovtsov and Glotov, 2001). The age of greenschists, 106-108 Ma (samples 98116/2 and 98117/3), cannot be interpreted unambiguously. These ages might reflect either the time of exhumation of rock complexes of the accretionary prism or the peak (104-108 Ma) of metamorphism and deformation in eastern Chukotka (Bering Strait Geologic Field Party, 1997). The youngest age $98 \mathrm{Ma}$ (sample C-2572/9) is most likely the result of the enormous amount of heat generated during the formation of the Okhotsk-Chukotka volcanic belt, whose volcanics overlap the eastern part of the South Anyui terrane (Fig. 3).

Acknowledgements. We use this opportunity to express our gratitude to the organizers (D. Stone, E. Miller, K. Fujita, W. Nokleberg, P. Layer, J. Hourigan) and sponsors of the conference "Joint US-Russia Workshop on the Plate Tectonic Evolution of Northeast Russia" and Special Session of AGU 2004 in honor of our colleague and friend Leonid Parfenov (Title: Origins of Northeast Russia: Paleomagnetism, Geology and Tectonics). This study was supported by the Russian Foundation of Basic Research (project no. 0505-65052; 08-05-00547), project of FCNTP (NSh-3172.2008.5), Department of Earth Sciences of RAS (program nos. 6, 14). We are gratefull to J. Toro, B. Natal'in, and an anonymous reviewer for helpful and valuable remarks and suggestion that were very useful during the revision of the manuscript.

\section{References}

Bering Strait Geologic Field Party: Koolen metamorphic complex, northeastern Russia: Implications for the tectonic evolution of the Bering Strait region, Tectonics, 16, 713-729, 1997.

Bondarenko, G. Ye.: Tectonics and Geodynamic evolution of the Mesozoic fold belts along Northern Circum-Pacific, Moscow State University, 2004.

Bondarenko, G. Ye. and Luchitskaya, M. V.: Tectonic evolution of the Alyarmaut uplift, Western Chukotkaa, NE Asia, Byulleten' Moskovskogo Obshchestva Ispytatelei Prirody, Seria Geologicheskaya, 3, 18-27, 2003 (in Russian).

Bychkov, Yu. M. and Solov'yov, G. I.: New Data on the Stratigraphy and Lithology of Triassic Sediments in the Upper Reaches of the Bol'shoi Anyui River, Lower Mesozoic Deposits of the Right Side of the Kolyma River and Northwestern Kamchatka, Severo-Vostochnyi Kompleksnyi NauchnoIssledovatel'skyi Institut Rossiyiskoi Akademii Nauk, Magadan, 3-24, 1992 (in Russian).

Cecile, M. P., Lane, L. S., Kos'ko, M. K., Bychkov, Yu. M., Vinogradova, O. N., and Gorodinsky, M. E.: Joint visit of Canadian and Soviet scientists to the northeastern Soviet Union, Episodes, 14, 125-129, 1991.

Chekhov, A. D.: Tectonic evolution of Northeastern Asia, Nauka, Moscow, 2000 (in Russian).

Churkin Jr., M.: Tectonostratigraphic terranes of Alaska and Northeastern USSR - a record of collision and accretion, Accretion tectonics in the Circum-Pacific regions, Tokyo, 37-42, 1983.

Cowan, D. S.: Structural style in Mesozoic and Cenozoic melanges in the western Cordillera of North America, Geological Society of America, Bulletin, 96, 451-462, 1985. 
Drachev, S. S. and Savostin, L. A.: Ophiolite of Bolshoi Lyakhovsky Island (Novosibirsk Archipelago), Geotektonika, 3, 98--107, 1993 (in Russian).

Fujita, K. and Newberry, T.: Tectonic evolution of Northeastern Siberia and adjacent regions, Tectonophysics, 89, 337-357, 1982.

Ganelin, A. V. and Silantyev, R. A.: Gabbroids of the Gromadnensky-Vurguveem peridotite-gabbro massif (western Chukotka) and their geodynamic interpretation, Dokl. Akad. Nauk SSSR+, 394, 225-228, 2004 (in Russian).

Ged'ko, M. I., Postnikov, S. N., and Svirina, M. A.: A Geological Report on Cosmoaerogeological Mapping Quadrangles R-58, 59, 60, Q-57, 58, between 1988-1990, Aerogeologia, Ministry of Geology of Russia, Moscow, 1991 (in Russian).

Glotov, S. P.: A Report on the 1:50000 Geological Mapping and General Exploration, Quadrangle Q-58, between the Orlovka and Nutesyn Rivers between 1990-1995, Ministry of Geology of Russia, Anyuiskoe Gosudarstvennoe Gorno-Geologicheskoe Predpriyatie, Bilibino, 1995 (in Russian).

Golonka, J., Ross, M., and Scotese, C. R.: Phanerozoic paleogeographic and paleoclimatic modelling maps, Pangea: Global Environments and Resources, edited by: Embry, A. F., Beauchamp, B., and Glass, D., Canadian Society of Petroleum Geologists Memoir 17, 1-47, 1994.

Grantz, A., Clark, D. L., Phillips, R. L., and Srivastava, S. P.: Phanerozoic stratigraphy of Northwind Ridge, magnetic anomalies in the Canada basin, and the geometry and timing of rifting in the Amerasia basin, Arctic Ocean, Geological Society of America, Bulletin, 10, 801-820, 1998.

Grigoriev, V. N., Krylov, K. A., and Sokolov, S. D.: Accreted Mesozoic oceanic complexes of Koryak Superterrane, Northeastern Russia. Proceedings of the 1992 International Conference on Arctic Margins, edited by: Thurston, D. K. and Fujita, K., Anchorage, 217-222, 1994.

Kosygin, Yu. A., Voevodin, V. N., Zhitkov, N. G., and Solov'yov, V. A.: Eastern Chukotka volcanic zone and tectonic nature of volcanic belts, Dokl. Akad. Nauk SSSR+, 216, 885-888, 1974 (in Russian).

Korago, E. A.: Magmatic associations of the Bolshoy Anyui River as indicators of past geodynamic environments and protracted/discrete evolution of the South Anyui fold zone. Magmatism and metamorphism of Northeast Asia, Proceedings of the IV regional petrographic conference on Northeastern Russia, Magadan, 187-190, 2000 (in Russian).

Kuz'michev, A. B., Sklyarov, E. V., and Barash, I. G.: Pillow basalts and glaucophane schists in Bolshoy Lyakhovsky Island (Novosibirskie Islands): fragments of the lithosphere of the South Anyui paleocean, Geol. Geofiz., 46, 1367-1381, 2005 (in Russian).

Kuz'michev, A. B., Solov'yov, A. V., and Gonikberg, A. V.: Syncollisional Mesozoic terrigenous deposits of Bolshoy Lyakhovsky Island (Novosibirskie Islands), Stratigrafia i Geologocheskaya Korrelyatsiya, 14, 33-53, 2005 (in Russian).

Lanphere, M. A. and Dalrymple, G. B.: First-principles calibration of ${ }^{38} \mathrm{Ar}$ tracers: Implications for the ages of ${ }^{40} \mathrm{Ar} /{ }^{39} \mathrm{Ar}$ fluence monitors, US Geological Survey Professional Paper, 1621, 2000.

Layer, P. W.: Argon-40/Argon-39 age of the El'gygytgyn impact event, Chukotka, Russia, Meteorit. Planet. Sci., 35, 591-599, 2000.
Layer, P. W., Hall, C. M., and York, D.: The derivation of ${ }^{40} \mathrm{Ar} /{ }^{39} \mathrm{Ar}$ age spectra of single grains of hornblende and biotite by laser step heating, Geophys. Res. Lett., 14, 757-760, 1987.

Layer, P. W., Newberry, R., Fujita, K., Parfenov, L., Trunilina, V., and Bakharev, A.: Tectonic Setting of the Plutonic Belts of Yakutia, Northeast Russia, based on ${ }^{40} \mathrm{Ar} /{ }^{39} \mathrm{Ar}$ Geochronology and Trace Element Geochemistry, Geology, 29, 167-170, 2001.

Lychagin, P. P.: Aluchin massif and the role of ophiolitic ultramafites and gabbroids in the Mesozoides of the Northeast USSR, Tikhookean. Geol.a, 5, 33-41, 1985 (in Russian).

Lychagin, P. P., Byalobzhessky, S. G., Kolyasnikov, Yu. A., Korago, Ye. A., and Likman, V. B.: The Magmatic History of the South Anyui Folded Zone, Geology of Continent-Ocean Transition Zone in Northeast Asia, Severo-Vostochnyi Kompleksnyi Nauchno-Issledovatel'skyi Institut Rossiyiskoi Akademii Nauk, Magadan, 140-157, 1991 (in Russian).

Lychagin, P. P.: The Volcanic Complexes of the South-Anyui fold zone, in: Magmatism and Mineral Deposits of NorthEast Russia, edited by: Byalobzhesky, S. G., Severo-Vostochnyi Kompleksnyi Nauchno-Issledovatel'skyi Institut Rossiyiskoi Akademii Nauk, Magadan, 17-33, 1997 (in Russian).

McDougall, I. and Harrison, T. M.: Geochronology and Thermochronology by the ${ }^{40} \mathrm{Ar} /{ }^{39} \mathrm{Ar}$ method, Oxford University Press, New York, 2nd edn., 1999.

Miller, E. L, Gelman, M., Parfenov, L., and Hourigan, J.: Tectonic setting of Mesozoic magmatism: A comparison between northeastern Russia and the North American Cordillera, edited by: Miller, E. L., Grantz. A., and Klemperer, S. L., Tectonic Evolution of the Bering Shelf-Chukchi Sea-Arctic Margin and Adjacent Landmasses, Boulder, Colorado, Geological Society of America. Special Paper 360, 313-332, 2002.

Miller, E. L. and Hudson, T. L.: Mid-Cretaceous extensional fragmentation of the Jurassic-Cretaceous compressional orogen, Alaska, Tectonics, 10, 781-796, 1991.

Miller, E. L., Toro, J., Gehrels, G., Amato, J. M., Prokopiev, A., Tuchkova, M. I., Akinin, V. V., Dumitru, T. A., Moore, T. E., and Cecile, M. P.:

New insights into Arctic paleogeography and tectonics from $\mathrm{U}-\mathrm{Pb}$ detrital zircon geochronology, Tectonics, 25, TC3013, doi:10.1029/2005TC001830, 2006.

Natal'in, B. A.: Early Mesozoic Eugeosynklinal Systems in the Northern Part of the Circum-Pacific Belt, Nauka, Moscow, 1984 (in Russian).

Natal'in, B. A., Amato, J. M., Toro, J., and Wright, E.: Paleozoic rocks of northern Chukotka Peninsula, Russian Far East: Implications for tectonics of the Artic region, Tectonics, 18, 6, 9771003, 1999.

Nokleberg, W. J., Parfenov, L. M., Monger, J. W. H., Baranov, B. V., Byalobzhesky, S. G., Bundtzen, T. K., Feeney, N. D., Fujita, K., Gordey, S. P., Grantz, A., Khanchuk, A. I., Natalin, B. A., Natapov, L. M., Norton, I. O., Patton, W. W., Plafker Jr., G., Scholl, D. W., Sokolov, S. D., Sosunov, G. M., Stone, D. B., Tabor, R. W., Tzukanov, N. V., Vallier, T. L., and Wakita, K.: CircumNorth Pacific Tectonostratigraphic Terrane Map, US Geol. Surv., Open File Report 94-714, scale 1:5000 000, 1994.

Nokleberg, W. J., Parfenov, L. M., Monger, J. W. H., Norton, I. O., Khanchuk, A. I., Stone, D. B., Scholl, D. W., and Fujita, K.: Phanerozoic Tectonic Evolution the Circum-North Pacific, U.S. Geological Survey, Open-File Report 98-754, 1998. 
Oxman, V. S., Ganelin, A. V., Sokolov, S. D., Morozov, O. L., Tretyakov, F. F., and Silantyev, R. A.: Ophiolitic belts of the Arctic regions of the Verkhoyansk-Chukotka orogenic area: A geodynamic model of formation, Tikhookean. Geol., 22, 62-75, 2003 (in Russian).

Palymskyi, B. F.: Middle Paleozoic granitodes of the Bol'shoi Anyui river (new data) [Materialy po geologii i poleznym iskopaemym Severo-Vostoka SSSR], Magadan: Khizhnoe Izdatel'stvo, 19, 41-55, 1966 (in Russian)

Parfenov, L. M.: Continental Margins and Island Arcs in the Mesozoides of Northeastern Asia, Novosibirsk: Nauka, 1984 (in Russian).

Parfenov, L. M.: Geological structure and geological history of Yakutia. Geological Monuments of the Sakha Republic (Yakutia), Novosibirsk, 1997 (in Russian).

Parfenov, L. M. and Natal'in, B. A.: Tectonic evolution of Northeastearn Asia in the Mesozoic and Cenozoic, Dokl. Akad. Nauk SSSR+, 235, 1132-1135, 1977 (in Russian).

Parfenov, L. M., Natapov, L. M., Sokolov, S. D., and Tsukanov, N. V.: Terranes analysis and accretion in northeast Asia, The Islands Arc, 2, 35-54, 1993.

Pinus, G. V. and Sterligova, V. Ye.: A New Alpine-Type Hyperbasite Belt in the Northeast USSR, Geol. Geofiz., 14, 109-111, 1973 (in Russian).

Radziwill, A. Ya. and Radziwill, V. Ya.: Late Jurassic Magmatic Associations of the South Anyui Depression, Magmatism of Northeastern Asia, Knizhnoe Izdatel'stvo, Magadan, 2, 71-80, 1975 (in Russian).

Ruzhentsev, S. V. and Aristov, V. A.: New data on the Polar Ural Geology, The Ural the basic problems of geodynamics and stratigraphy, Nauka, Moscow, GIN Reports, 500, 25-41, 1998 (in Russian).

Samson, S. D. and Alexander, E. C.: Calibration of the interlaboratory ${ }^{40} \mathrm{Ar} /{ }^{39} \mathrm{Ar}$ dating standard, MMhb1, Chem. Geol., 66, 27-34, 1987.

Savostin, L. A., Natapov, L. M., and Stavskiy, A. P.: Mesozoic paleogeodynamics and paleogeography of the Arctic region. Paleooceanology. Doklady. Colloquium, 27 International Geological Congress, Moscow, Colloquium 03, 172-187, 1984.

Seslavinskiy, K. B.: The South Anyui Suture (Western Chukotka), Dokl. Akad. Nauk SSSR+, 249, 1181-1185, 1979 (in Russian).

Sizykh, V. I., Ignatyev, V. A, Shkol'nyi, L. D., Berlimble, D. G., Fomin, V. P., Redyuk, R. R., and Sukhonina, R. R.: New data on the stratigraphy and tectonics of the left-side areas of the Malyi Anyui R., Materials on geology and economic minerals of the northeastern USSR, Knizhnoe Izdatelstvo, Magadan, 23, Book 1, 29-34, 1977 (in Russian).

Shapiro, M. N. and Ganelin, V. G.: Paleogeodynamic interrelations in the large blocks of the Mesozoic of the north-eastern USSR, Geotektonika, 5, 94-104, 1988 (in Russian).

Shekhovtsov, V. A. and Glotov, S. P.: State Geological map of the Russian Federation, scale 1:200000, Oloy Series, Quadrangle Q-58-XI, XII, Explanatory note, edited by: Sokolov, S. D., Anyuiskoe Gosudarstvennoe Gorno-Geologicheskoe Predpriyatie, Ministerstvo Prirodnykh Resursov, Moscow, 2001 (in Russian).

Sokolov, S. D., Bondarenko, G. Ye., Morozov, O. L., Ganelin, A. V., and Podgorny, I. I.: Nappes tectonics of the South Anyui suture zone (western Chukotka), Dokl. Akad. Nauk SSSR+, 376, 80-
84, 2001 (in Russian).

Sokolov, S. D., Bondarenko, G. Ye., Morozov, O. L., Shekhovtsov, V. A., Glotov, S. P., Ganelin, A. V., and Kravchenko-Berezhnoy, I. R.: The South Anyui Suture, NE Arctic Russia: facts and problems to solve, Tectonic Evolution of the Bering Shelf-Chukchi Sea-Arctic Margin and Adjacent Landmasses, edited by: Miller, E. L., Grantz. A., and Klemperer, S. L., Boulder, Colorado, Geological Society of America, Special Paper 360, 209-224, 2002.

Sokolov, S. D., Bondarenko, G. E., Tuchkova, M. I., and Layer, P. W.: Tectonic setting and origin of sedimentary-volcanic deposits of the Polyarninskoe uplift (South Anyui suture, West Chukotka), Dokl. Akad. Nauk SSSR+, 411(8), 1199-1202, 2006,

Sokolov, S. D., Didenko, A. N., Grigoriyev, V. N., Alexyutin, M. V., Bondarenko, G. Ye., and Krylov, K. A.: Paleotectonic Reconstrucrtions of Norteastern Russia: Problems and Uncertainties, Geotektonika, 6, 72-90, 1997, (in Russian).

Spektor, V. B., Andrusenko, A. M., Dudko, E. A., and Kareva, N. F.: Continuation of the South-Anyui suture in Primorsk Island, Dokl. Akad. Nauk SSSR+, 260, 1447-1450, 1981 (in Russian).

Steiger, R. H. and Jaeger, E.: Subcommission on geochronology: Convention on the use of decay constants in geo and cosmochronology, Earth Planet. Sc. Lett., 36, 359-362, 1977.

Ti'lman, S. M., Afizky, A. I., and Chekhov, A. D.: Comparative Tectonics of the Alazeya and Oloi zones (North-East of the USSR) and the Kolyma massif problem, Geotektonika, 4, 6-17, 1977 (in Russian).

Ti'lman, S. M., Byalobzhesky, R. G., Chekhov, A. D., and Krasny L. L.: The peculiarities of formation of continental crust in the northeastern USSR, Geotektonika, 6, 15-29, 1975 (in Russian).

Ti'lman, S. M. and Bogdanov, N. A.: Tectonic Map of Northeast Asia, Scale 1:500 000, edited by: Pushcharovsky, Yu. M., Institute of the Lithosphere, Moscow, 1992 (in Russian),

Tuchkova, M. I., Miller, E. L., Gehrels G. E., Toro, H. P., Amato, D., and Katkov, R. M.: Paleoreconstructions of the Triassic basin of western Chukotka based on zircon dating results, Areas of active tectogenesis in the modern and ancient history of the Earth. GEOS, Moscow, 2, 324-327, 2006 (in Russian).

Tuchkova, M. I., Bondarenko G. Ye., Miller, E. L., Buyakaite, M. I., Gehrels G. E., Golovin, D. I., Galuskina, I. O., and Pokrovskaya, E. V.: Results from sedimentological and radiometric studies of the Upper Triassic deposits of the Chukotka microcontinent, Geotektonika, 5, 76-96, 2007 (in Russian).

Tynankergav, G. A. and Bychkov, J. M.: Upper Triassic ChertVolcanic-Terrigeneous Assemblages of Western Chukotka, Dokl. Akad. Nauk SSSR+, 296, 698-700, 1987 (in Russian).

Ustritsky, V. I. and Khramov, A. N.: History of forming Northern part of Pacific ocean and Circum Pacific belt (juxtaposition of paleomagnetic and paleogeographic data from adjacent land), Geology of the Northwestern Part of the Pacific Belt, edited by: Pushcharovsky, Yu. M., Academy of Sciences of the USSR, Moscow, 239-276, 1987 (in Russian).

Vishnevskaya, V. S.: Radiolarian biostratigraphy of the Jurassic and Cretaceous of Russia, GEOS, Moscow, 2001 (in Russian).

York, D., Hall, C. M., Yanase, Y., Hanes, J. A., and Kenyon, W. J.: ${ }^{40} \mathrm{Ar} /{ }^{39} \mathrm{Ar}$ dating of terrestrial minerals with a continuous laser, Geophys. Res. Lett., 8, 1136-1138, 1981.

Zonenshain, L. P., Kuzmin, M. I., and Natapov, L. M.: Plate Tectonics of the USSR Territory, 2, Moscow, Nedra, 1990 (in Russian) 